\section{Ankara Üniversitesi Eğitim Bilimleri Fakültesi Özel Eğitim Dergisi}

2022, 23(1), 1-21
ARAŞTIRMA

Gönderim Tarihi: 01.07.20

Kabul Tarihi: 18.02.21

Erken Görünüm: 07.04.21

\title{
Özel Gereksinimli Bireyleri Konu Alan Okul Öncesi Dönem Resimli Öykü Kitaplarının İncelenmesi
}

\author{
Hüseyin Öztürk $(\mathbb{D}) 1$
}

\author{
Kemal Afacan ${ }^{(\mathbb{D})} 2$
}

\author{
Seden Demirtaş-İlhan $(\mathbb{D} 3$
}

$\ddot{O} \mathbf{z}$

Giriş: Özel gereksinimli bireylere karşı toplumsal duyarlılığı artırmak ve onların yaşantılarını zorlaştıran birtakım davranışların önüne geçebilmek için okul öncesi dönemden itibaren yapılacak bilinçlendirme çalışmalarına ihtiyaç vardır. Çocuk edebiyatı, bu çalışmaları zenginleştirmek ve derinleştirmek adına olanaklar sunmaktadır. Okul öncesi dönemde, resimli öykü kitapları aracıllğı ile gerçekleştirilecek okuma çalışmaları, özel gereksinimli bireylerle ilgili deneyimi olmayan çocukların söz konusu bireylere yönelik duyarlılıklarının artırılmasında yararlı olacaktır.

Yöntem: Bu araștırmada, özel gereksinimli bireyleri konu alan ve 2000 yılından itibaren yayımlanmış olan okul öncesi dönem resimli öykü kitapları içerik analizi kullanılarak incelenmiştir. Toplamda 20 kitap bu çalışma kapsamında incelenecek kitaplar listesine dâhil edilmiş̧ir. Uluslararası alanyazında yer bulmuş değerlendirme ölçekleri işe koşularak gerçekleştirilen bu araştırmada, söz konusu kitaplarda yer alan özel gereksinimli bireylerin kişisel özellikleri, karakter özellikleri, karakter tasvirleri, karakter gelişimleri ve hikâyenin bakış açısına ait bilgilerin yanı sıra özel gereksinimi olan ve olmayan karakterler arasındaki ilişkiler incelenmiştir.

Bulgular: İncelenen 20 resimli öykü kitabında sekiz farklı özel gereksinim durumu tespit edilmiştir. İncelenen 20 kitabın altısında fiziksel yetersizlik, dördünde işitme yetersizliği, üçünde zihin yetersizliği, ikisinde disleksi, ikisinde dikkat eksikliği ve hiperaktivite bozukluğu, birinde görme yetersizliği, birinde otizm, birinde de konuşma bozukluğu konu edilmiştir.

Tartışma: İncelenen kitaplardaki özel gereksinim durumlarının çeşitliliği benzer geçmiş araştırmalarla örtüşürken karakter gelişimi ve karakterler arası ilişkilere yönelik sonuçlar farklılık göstermektedir. Bu araştırma, özel gereksinimli bireylere yönelik farkındalık kazandırabilecek resimli öykü kitaplarını belirlemiş ve okuma programı önerilerinde bulunmuştur.

Anahtar sözcükler: Okul öncesi, çocuk, resimli öykü kitabı, yetersizlik, özel gereksinim.

Atıf için: Öztürk, H., Afacan, K., \& Demirtaş-İlhan, S. (2022). Özel gereksinimli bireyleri konu alan okul öncesi dönem resimli öykü kitaplarının incelenmesi. Ankara Üniversitesi Ĕgitim Bilimleri Fakültesi Özel Ĕgitim Dergisi, 23(1), 1-21. https://doi.org/10.21565/ozelegitimdergisi.761001

\footnotetext{
${ }^{1}$ Sorumlu Yazar: Dr. Öğr. Üyesi, Artvin Çoruh Üniversitesi, E-posta: hsynztrk42@artvin.edu.tr, https://orcid.org/0000-00032876-4734

${ }^{2}$ Dr. Öğr. Üyesi, Artvin Çoruh Üniversitesi, E-posta: kemalafacan@artvin.edu.tr, https://orcid.org/0000-0002-2691-6397

${ }^{3}$ Arş. Gör., Artvin Çoruh Üniversitesi, E-posta: sedendemirtas@ artvin.edu.tr, https://orcid.org/0000-0003-2447-8482
} 


\section{Giriş}

Çocuk kitapları, özel gereksinim konusunda çocukların farkındalık kazanması için ișe koşulabilecek kaynaklardan biridir. Özel gereksinimli bireyler ile doğrudan temas kurmak, hem tipik gelişim gösteren bireyleri hem de özel gereksinimli bireyleri olumlu yönde etkilemektedir (Sucuoğlu vd., 2020). Ancak bütün çocukların özel gereksinimli bireylerle doğrudan ve sürekli iletişim kurma firsatı olamayabilmektedir. Kitaplar, çocuklara doğrudan deneyimleyemedikleri yaşantıları deneyimlemeleri için birtakım olanaklar sunmaktadır. Lukens'in (2002) deyişiyle bizim kendi hayatımızdan başka hayatları yaşamamız fiilen olanaksızdır, ancak edebiyat bunu bizim için mümkün kılmaktadır. Bu cümle Sever'in (2012) ifadeleriyle genişletilecek olursa edebiyat, çocuğun insanı ve çevreyi tanımasına dolayısıyla insana ait olguları tanımasına ortam hazırlamakta ve kendi yaşantılarıyla kurgusal yaşantılar arasında bağ kurarak çıkarımlarda bulunmasına imkân tanımaktadır. Bütün bu imkânlar özel gereksinim konusu için de geçerlidir. Ayrıca çocuk kitapları, konuyla ilgili deneyimi olmayan çocukların yanı sıra özel gereksinimli bireylerin yakın çevresine (ebeveynleri, öğretmenleri, kardeşleri vb.) de söz konusu özel gereksinim durumuna dair daha ayrıntılı düşünebilmesi için firsatlar sunmaktadır. Ayrıca okuyuculara olası problemlere yönelik çözümleri görebilmesi için yaşantı örnekleri sunabilmektedir. Eğitim sürecinin her aşamasında öğrencileri özel gereksinim temalı eserlerle buluşturmak ve söz konusu eserler hakkında sorular sorma, düşünme, tartı̧̧a ve çıkarım yapma imkânı sunmak, toplumun özel gereksinimli bireyler karşısında zaman zaman sergilediği bilinçsiz tutumların en aza indirilmesine katkı sağlayacaktır. Bu sebeple çocuklara yönelik eserlerde özel gereksinimli bireylerin durumunu gözden geçirmekte yarar vardır çünkü bu kitaplar birtakım hatalı yaklaşım ve tutumlar içerebilmektedir. Hâlihazırda bu tür durumlar, bazı araştırmacıların da dikkatini çekmiştir.

Rubin ve Watson (1987), çocuklar için de pek çok uyarlaması yapılmış klasik eserlerde özel gereksinimli karakterlerin çoğunlukla olumsuz ve gerçekçi olmayan özellikleri ile belirtildiğini tespit etmiştir. Bu araştırmacılar, söz konusu eserlerde özel gereksinimli bireyler için kullanılan 11 farklı kalıp tip belirlemiş̧ir. Bu tipler acınacak bir varlık olarak resmedilenlerden şiddet nesnesi olanlara, kendi kendisine acıyanlardan topluma bir yük olarak tasvir edilenlere, toplumdan tecrit edilmiş olanlardan kötücül özelliklere sahip olanlara kadar geniş bir çeşitlilik göstermektedir. Charles Dickens'ın Noel Şarkısı romanındaki Küçük Tim, Fareler ve İnsanlar'daki Lennie, Heidi romanında yer alan Clara yukarıdaki araştırmacıların verdikleri çok sayıda örnekten birkaçıdır. Pek çok çocuk, çocuk edebiyatındaki özel gereksinimli karakterlerin bu özelliklerini öğrenerek büyümüştür. Ancak özel gereksinimli karakterler için çizilen bu olumsuz portre bugünün çağdaş toplumunda yetişecek çocuklar için uygun bulunmamaktadır (Dyches vd., 2001). Özel gereksinimli bireyler geçmişe kıyasla bugün topluma daha fazla aktif katılım göstermektedir. Ayrıca içerisinde yaşadıkları topluma pek çok alanda olumlu katkılar sağlamaktadır. $\mathrm{Bu}$ yüzden eserlerde sunulan özel gereksinimli karakterin özelliklerinin gerçekçi ve içinde yaşanılan çağın beklentilerine uygun olması özel gereksinimli bireylerin sosyal kabulüne yönelik farkındalığı artıracaktır (Leininger vd., 2010). Bir başka deyişle, özel gereksinimli bireylerin devinimsel (topluma katılım sağlayabilen, çok yönlü, etkileşime ve iş birliğine açık) karakterler olarak betimlenmesi, durağan (basmakalıp, asosyal, üretken olmayan, değişime kapalı) karakterler olarak betimlenmemesi toplumsal bakış açısının değişiminde oldukça önemlidir.

Alanyazın incelendiğinde, son yıllarda kahramanları özel gereksinimli karakterler içeren çok sayıda bağımsız eserin yanı sıra Türkiye Bilimsel ve Teknolojik Araştırma Kurumu (TÜBİTAK), Yapı Kredi Yayınları gibi kuruluşların konuyla ilgili yayın dizileri çıkardığı dikkat çekmektedir. Bu kitapların özel gereksinimli karakterlere yönelik olumlu bir portre çizmesi gerekmektedir. Olumlu tasvirler; (a) özel gereksinimli bireyler için yüksek beklentiler öngörülen, (b) olumlu katkıların göz önüne çıkarıldığı, (c) güçlü yönlerin geliştirildiği, (d) bireylerin seçimlerinin ön plana çıkarıldığı, (e) diğer bireylerle gelişen karşılıklı ilişkilerin tasvir edildiği, (f) özel gereksinimli bireylerin diğer bireylerle eşit vatandaşlık haklarına sahip olduğunun garanti edildiği betimlemelerdir (Dyches \& Prater, 2005). Ayrıca nitelikli çocuk edebiyatı eserlerinde karakterler özel gereksinimli olsun ya da olmasın güvenilir, tutarlı, çok yönlü ve sürekli gelişen bireyler olarak tasvir edilmelidir (Dyches \& Prater, 2000). Gerçekçilik, karakterlerin sahip olduğu yetersizlik türünün bütün fiziksel, davranışsal ve dil ile ilgili özelliklerini gösteriyor olması anlamına gelmektedir (Dyches vd., 2001). Ayrıca karakterlerin özelliklerinin devinimsel olduğunun ve zaman içerisinde olumlu bir gelişim gösterebileceğinin belirtilmesi gerekmektedir (Dyches \& Prater, 2000).

Konuyla ilgili bütün paydaşların yararlanabilmesi için özel gereksinimli bireyleri konu alan Türkçe olarak yayımlanmış eserlerin tespiti, belirli nitelikler bakımından incelenmesi ve sınıflandırılması, söz konusu kitaplara ihtiyaç duyabilecek araştırmacı, psikoterapist, öğretmen, ebeveyn ve öğrenciler için yararlı olacaktır. Alanyazında konuyla ilgili bazı araştırmalar mevcuttur (Blaska, 2004; Dyches \& Prater, 2000; Gürdal-Ünal, 2014). Örneğin, Prater (1999) zihin yetersizliği olan karakterlerin yer aldığı 1965-1996 yılları arasında yayımlanmış 68 çocuk 
kitabının içerik analizini yapmıştır. Prater, zihin yetersizliği olan toplam 77 karakterin \%61'nin yan karakter olduğunu bulmuştur. Ayrıca karakterlerin \%54'ünün hikâye boyunca durağan olduklarını ve başlangıçta bulundukları durumdan daha iyiye gitmediklerini tespit etmiştir. Hikâyelerin sadece \%13'ü zihin yetersizliği olan karakterler tarafindan anlatılmıştır. Dyches ve diğerleri (2001) zihin yetersizliği ve otizm spektrum bozukluğu olan karakterlerin yer aldığı 1997-1998 yıllarında yayımlanmış 12 kitabı özel gereksinimli karakterin kurgudaki yeri, kurgunun türü, özel gereksinimli karakterin özellikleri bakımından incelemiştir. Kitaplardaki toplam 14 karakterin \%50'sinin ana karakter olarak hikâyelerde yer aldığı belirlenmiştir. Karakterlerin \%64'ü gerçekçi ve \%71'i olumlu özellikleri (sosyal katılım, üretkenlik vb.) ile belirtilmiştir. Karakterlerin \%50'si hikâyeler boyunca durağan bir hâldedir. Dyches ve Prater (2005) tarafından gerçekleştirilen bir başka çalışma, gelişimsel yetersizliği olan karakterlerin yer aldığı 1999-2003 yılları arasında yayımlanmış 34 kitabın incelemesini sunmuştur. Araştırmacılar bu incelemede gelişimsel yetersizliği olan karakterlerin çoğunlukla kendi tercihlerini yapabildiklerini, kapsayıcı eğitim ortamlarında eğitim gördüklerini ve içinde yaşadıkları toplum tarafından daha fazla kabul edildiklerini ortaya koymuşlardır. Ayrıca kitaplarda gelişimsel yetersizliği olan karakterlerin vatandaşlık bilincine sahip olma, sosyal hayata katılabilme, iletişim kurabilme, sportif ya da sanatsal faaliyetlerde bulunabilme, çeşitli alanlarda üretkenlik gösterebilme, unutkan ya da dalgın olma, heyecanlı veya neşeli olma gibi pek çok özelliğe sahip olduğu, yetersizliklerinin bu özelliklerden sadece birisi olduğu vurgulanmıştır.

Türkiye'de çocuklar için yayımlanmış ve özel gereksinimli bireyleri ele alan eserleri inceleyen çalışmalardan biri Gürdal-Ünal (2014) tarafından gerçekleştirilmiştir. 1969-2009 arasında yazılmış 40 kitabı içeren bu araştırma özel gereksinimli bireylerin hayat şartlarındaki değişimin ve bu bireylerin çocuk edebiyatında nasıl temsil edildiğinin izlerini sürmeye çalışmıştır. Bu araştırmada nicel veriler paylaşılmamış, ancak eserlerden örneklerle özel gereksinimli bireylerin aile, okul, arkadaş ve dış çevre ile ilişkilerinin seyri ortaya çıkarılmıştır. Araştırmanın sonuçlarında, özel gereksinimli bireylerin tarihsel süreç içinde durağan ve olumsuz özelliklerinden sıyrılıp dinamik ve üretken bireyler olarak temsil edildikleri; aileleri için utanılacak kişi olmaktan çıkıp başarılarıyla gurur duyulacak kişilere dönüştükleri tespit edilmiştir. Bununla birlikte, zaman zaman aksi örneklerin de bulunduğu, bir başka deyişle özel gereksinimli olan kurgusal kahramanların zaman zaman çevresine yük olarak betimlendiği, üretmeyen ve toplumsal katkısı olmayan kimseler olarak gösterildiği yine eserlerden alıntılarla ifade edilmiştir. Öte yandan Kaymaz'ın (2017) 10 farklı yayınevinden çıkan ve özel gereksinimli bireyleri konu edinen toplam 61 resimli öykü kitabını analiz ettiği tez çalışması bu araştırmalara örnektir. Erken çocukluk dönemini de kapsayan 3-8 yaş arası çocuk kitaplarının içerik analizi yöntemi ile tarandığı bu çalışmada kitapların temel özelikleri, temel bileşenleri ve biçim özellikleri ele alınmıştır. Çalışmanın sonuçları doğrultusunda karakterlerin daha çok insan, erkek, erken çocukluk döneminde, ana karakter, dinamik ve olumlu (özbakım becerileri olan, sağlıklı iletişim kurabilen, topluma katkı sağlar bir hâlde) olarak tasvir edildikleri ortaya konulmuştur. Ayrıca kitaplarda en çok yer verilen yetersizlik grupları, uyum bozukluğu ile duygu ve davranış problemleri iken en az değinilen yetersizlik grupları zihin yetersizliği, işitme yetersizliği, dil ve konuşma bozukluklarıdır. Özel gereksinimli bireylerin toplumdaki yeri ve katkılarının belirlenmesine yönelik olarak incelenen kitaplar içerisinde özel gereksinimli bireylerin problemli durumlarda genellikle yardım alan taraf olarak tasvir edildiği, zaman zaman hem yardım alan hem yardım eden durumunda oldukları fakat çok az sayıda eserde yardım eden konumunda oldukları belirtilmiştir. Görüldüğü üzere konuyla ilgili az sayıda araştırmanın sonuçları ele aldıkları örnekleme ve araştırma yöntemine göre çeşitlilik göstermektedir. Özel gereksinim durumunun türü, özel gereksinimi olan kahramanın nitelikleri, eserlerin hitap ettiği kitle araştırmaların merkezinde yer almaktadır. Özellikle okul öncesi döneme yönelik çocuk kitaplarına ilişsin araştırmaların sınırlı oluşu bu konunun enine boyuna araştırılmasını gerekli kılmaktadır. Özellikle özel gereksinimli bireyleri çok yönlü bir biçimde sunarak etkileşimli okuma faaliyetlerine imkân tanıyacak eserlerin tespiti ve nesnel ölçütlerle değerlendirilmesi gerekmektedir.

Güncel alanyazında kapsayıcı okul öncesi eğitime hazırlık için etkileşimli okuma faaliyetlerinin önemi vurgulanmaktadır. Çocuklara eserin kahramanları ve bağlamı hakkında açık uçlu sorular sorulması ve alınan yanıtların tekrar edilerek daha anlaşılır kılınması gerektiğinin altı çizilmektedir (Ergül vd., 2014; Odluyurt, 2018). Olaya dayalı yapısıyla ve açıklayıcı çizimleriyle resimli öykü kitapları bu türden okumalara geniş imkân tanımaktadır. Ural'ın (2013) ifadesiyle bu kitaplarda hem gözün hem kulağın işittiği iki öykü var gibidir. Gözün gördüğü öykü görseller aracıllğı ile takip edilirken kulağın işittiği öyküde çocuğa kitabı okuyanın rolü belirginleşmektedir. Burada yetişkin ile çocuk arasında nitelikli ve sağlıklı bir iletişime kapı aralanmaktadır. Bu sebeple okul öncesi dönem için Türkçe alanyazında özel gereksinim temalı çocuk edebiyatı eserlerini işlevsel bir biçimde analiz eden araştırmalara ihtiyaç vardır. Mevcut alanyazın incelendiğinde bu ihtiyacı karşılamaya yönelik güncel bir çalışma olmadığı gözlemlenmektedir. Bu çalışma ile alandaki bu ihtiyacı karşılamak amaçlanmıştır. 
Mevcut çalışmanın amacı, özel gereksinimli bireyleri konu alan resimli öykü kitaplarını özel gereksinimli bireylerin tasviri başta olmak üzere, karakterlerin diğer özellikleri ve özel gereksinimi olmayan bireylerle ilişkileri açısından uluslararası çalışmalarda daha önce kullanılmış bir rehber (Dyches vd., 2001; Dyches \& Prater, 2005) aracılığ ile inceleyerek alanyazındaki bu eksikliğe katkı sunması açısından büyük önem taşımaktadır. Çalışma sunduğu sonuçlar ile hem okul öncesi öğretmenlere hem de velilere bir kitap listesi sunarak yol göstermektedir. Farklı ve çeşitli özel gereksinimlere sahip bireylerin konu alındığ kitapların çalışma grubuna dâhil edilmesi erken yaştaki çocukların bu özel gereksinimler hakkında bilgi sahibi olması ve farkındalık kazanabilmesini sağlamakta yardımcı olacaktır. İncelenen kitaplarda belirlenenen eksikliklerin alanda yazılacak yeni kitaplara öncülük etmesi ve bu eksikliklerin giderilmesine yardımcı olması öngörülmektedir.

\section{Yöntem}

Bu çalışmada okul öncesi dönem çocuklarına yönelik kaleme alınmış özel gereksinim temalı resimli öykü kitapları incelenmiştir. İnceleme sürecine 2000 yılından bugüne yayımlanan 20 okul öncesi dönem resimli öykü kitabı dâhil edilmiştir. Çalışma, içerik analiziyle gerçekleştirilmiştir. Denzin ve Lincoln'a (2000) göre nitel araştırma doğalcı ve yorumlayıcı özellikler taşıyan bir araştırma yöntemidir. Nitel çalışmanın doğasına uygun olarak içerik analizi; verilerin özetlendiği, sınıflandırıldığı ve yorumlandığı bir araştırma desenidir (Weber, 1990). $\mathrm{Bu}$ araştırmada da kitaplardan elde edilen veriler özetlenmiş, sınıflandırılmış ve yorumlanmıştır. Aşağıda kitapların belirlenme sürecine ve içerik analizinin gerçekleştirilmesine ilişkin ayrıntılar açıklanmıştır.

\section{Okul Öncesi Dönem Kitaplarının Belirlenmesi}

Kitap incelemesi çalışmalarında incelenecek eserlerin belirlenmesi büyük önem taşımaktadır (Dyches \& Prater, 2000). Seçilen eserler aynı zamanda çalışmanın örneklem grubunu oluşturmaktadır. Bu çalışmanın örneklemi için kullanılan ölçütler de okul öncesi dönem resimli öykü kitabı olması ve özel gereksinimli bireyleri konu almasıdır. Örnekleme sürecinde özel gereksinimli bireyleri konu alan ve erişilebilir durumda olan bütün okul öncesi dönem resimli öykü kitaplarına ulaşılmaya çalışıldığından ulaşılabilir basılı ve çevrimiçi kaynakların tamamından yararlanılmıştır. Bu çalışmada kullanılan kaynaklar şunlardır: Çevrimiçi satış yapan yayın grupları, çocuk edebiyatı tanıtım dergileri, sosyal ağlarda kitap tanıtım ve değerlendirme yazılarını paylaşan hesaplar, sorun odaklı çocuk edebiyatı eserlerini listeleyen çevrimiçi kataloglar. Bu kaynaklarda, çocuk edebiyatı eserleri hem tematik olarak hem de yaş grubuna göre sınıflandırıldığ iç̧in araştırmanın inceleme alanına girebilecek eserleri tespit edebilmek adına kolaylık sağlamıştır.

Kaynak taramasında kullanılmak üzere bazı anahtar kelimeler belirlenmiştir. Kullanılan anahtar kelimeler şunlardır: 'engel', 'yetersizlik', 'bozukluk', 'otizm', 'fiziksel', 'zihin', 'öğrenme güçlüğü', 'disleksi', 'işitme', 'görme', 'konuşma', 'dikkat eksikliği', 'hiperaktivite'. Kaynak taramasında 30 esere ulaşılmış, belirlenen dâhil etme ölçütlerini karşılayan eserler incelemeye alınmıştır. Bu amaçla dört ölçüt belirlenmiştir.

Birinci ölçüt, kitapların ilk baskısının 2000 yılından sonra yayımlanması olarak belirlenmiştir. Konuyla ilgili güncel eğilimleri tespit edebilmek için bu ölçüt dikkate alınmıştır. İkinci ölçüt, kitapların okul öncesi dönem çocuklarına yönelik hazırlanmış olmasıdır. Bu ölçüte uygun seçim yapabilmek için hem kitapların üzerinde belirtilen yas grubu etiketlerinden hem de uzman görüșünden yararlanılmıștır. Yaş grubunun belirlenmesinde Birleşmiş Milletler Eğitim, Bilim ve Kültür Örgütünün (United Nations Educational, Scientific and Cultural Organization, UNESCO) erken çocukluk tanımına başvurulmuştur. Bu tanıma göre erken çocukluk dönemi 0-8 yaş arasıdır (UNESCO, 2013). Üçüncü ölçüt kitapların özel gereksinimli karakter veya karakterler bulundurması olarak belirlenmiştir. "Özel gereksinimli birey çeşitli nedenlerle bireysel özellikleri ve eğitim yeterlilikleri açısından akranlarına göre beklenilen düzeyden anlamlı farklılık gösteren bireyi ifade etmektedir." (Cavkaytar, 2019, s. 5). Bu genel tanım, farklı özelliklere sahip özel eğitime gereksinimi olan çocukların tümünü kapsamaktadır. Milli Eğitim Bakanlığı Özel Eğitim Hizmetleri Yönetmeliğinde (2020) özel eğitim ihtiyacı olan birey "bireysel ve gelişim özellikleri ile eğitim yeterlilikleri açısından akranlarından anlamlı düzeyde farklılık gösteren bireyi” ifade etmektedir. Bu tanım kapsamında zihin yetersizliğine, görme yetersizliğine, işitme yetersizliğine, ortopedik yetersizliğe, otizme, dikkat eksikliği ve hiperaktivite bozukluğuna, duygu davranış bozukluklarına, dil ve konuşma bozukluğuna, özel öğrenme güçlüğüne ve üstün zekaya veya özel yeteneğe sahip karakterlere yer veren eserler çalışmaya dâhil edilmiştir. Son ölçüt kitapların resimli öykü kitabı özelliği taşıması olarak belirlenmiştir. Resimli öykü kitabı ifadesi, okul öncesi dönem çocuk edebiyatında oyuncak kitaplar, bez kitaplar, etkinlik kitapları ve kavram öğretimi amaçlı kitaplardan ayrı bir kategoriyi ifade etmek üzere kullanılmaktadır ve bir olay örgüsüne dayanmaktadır (Ural, 2013). Özel gereksinimli bireyleri gerçek hayat durumları içerisinde görebilmek için olaya dayalı bu kitaplar tercih edilmiştir. Kaynak taramasında tespit edilen kitaplardan 20'si ölçütleri karşıllayarak bu çalışma kapsamında incelenecek kitaplar listesine dâhil edilmiştir. 
İnceleme süreci sonunda 10 kitabın ölçütlere uygun olmadığ 1 tespit edilmiştir. Çalışmaya dâhil edilmeyen kitaplar ve neden dâhil edilmediklerine ilişkin açıklamalar Ek’te sunulmuştur. Bu kitaplar çalışma kapsamında incelenen kitaplar listesine dâhil edilmemiştir. Çalışma kapsamında incelenen 20 çocuk kitabı, yazar isimleri, resimleyenler, yayınevleri ve tavsiye edilen okuyucu yaşı Tablo 1'de sunulmuştur.

\section{Tablo 1}

Incelenen Kitaplar

\begin{tabular}{|c|c|c|c|c|}
\hline Kitap ismi & Yazar & Resimleyen & Yayınevi & Okuyucu yaşı \\
\hline $\begin{array}{l}\text { Yağmur adam ve en güzel } \\
\text { dans }\end{array}$ & Özge Bahar Sunar & Uğur Altun & Redhouse Kidz & Belirtilmemiş \\
\hline Kreşendo & Susanna Mattiangeli & Felicita Sala & Elma Çocuk & $\begin{array}{l}\text { Okul öncesi } \\
\text { dönem }\end{array}$ \\
\hline Farklı ama aynı & Feridun Oral & Feridun Oral & Yap1 Kredi Yayınları & Belirtilmemiş \\
\hline Şuşu, Can ve Dörtteker & Yıldıray Karakiya & Başak Günaçan & $\begin{array}{l}\text { Redhouse Kidz \& } \\
\text { SEV yayıncilık }\end{array}$ & Belirtilmemiş \\
\hline Riki'nin yeni dünyası & Aleix Cabrara & Rosa Maria Curto & $\begin{array}{l}\text { TÜBİTAK Popüler } \\
\text { Bilim Kitapları }\end{array}$ & $5+$ \\
\hline $\begin{array}{l}\text { Down sendromlu bir } \\
\text { arkadaşım var }\end{array}$ & Jennifer Moore-Mallinos & Marta Fabrega & $\begin{array}{l}\text { TÜBİTAK Popüler } \\
\text { Bilim Kitapları }\end{array}$ & $6+$ \\
\hline Dostluk engel tanımaz & Ayşen Oy & Volkan Akmeşe & Martı & Belirtilmemiş \\
\hline Barışın gezintisi & Laurie Lears & Karen Ritz & $\begin{array}{l}\text { TÜBİTAK Popüler } \\
\text { Bilim Kitapları }\end{array}$ & $7+$ \\
\hline $\begin{array}{l}\text { Berke'nin down sendromu } \\
\text { hikâyesi }\end{array}$ & Helena Kralic & Maja Lubi & $\begin{array}{l}\text { TÜBİTAK Popüler } \\
\text { Bilim Kitapları }\end{array}$ & $5+$ \\
\hline Gülümsemek iyidir & Mavisel Yener & $\begin{array}{l}\text { Esra İlter } \\
\text { Demirbilek }\end{array}$ & Tudem Yayın Grubu & Belirtilmemiş \\
\hline Greg'in zaferleri & Danielle Noreau & Stephane Jorisch & Yapı Kredi Yayınları & Belirtilmemiş \\
\hline Zoe zor öğreniyor & Marie-Claude Fortin & Lou Beachesne & Yapı Kredi Yayınları & Belirtilmemiş \\
\hline $\begin{array}{l}\text { Bir türlü yerimde } \\
\text { duramıorum }\end{array}$ & $\begin{array}{l}\text { Pam Pollack \& Meg } \\
\text { Belsivo }\end{array}$ & Marta Fabrega & $\begin{array}{l}\text { TÜBİTAK Popüler } \\
\text { Bilim Kitapları }\end{array}$ & $6+$ \\
\hline Bende disleksi var & Jennifer Moore-Mallinos & Marta Fabrega & $\begin{array}{l}\text { TÜBİTAK Popüler } \\
\text { Bilim Kitapları }\end{array}$ & $7+$ \\
\hline Duymamak böyle bir şey & Jennifer Moore-Mallinos & Marta Fabrega & $\begin{array}{l}\text { TÜBİTAK Popüler } \\
\text { Bilim Kitapları }\end{array}$ & $7+$ \\
\hline Yapabilirim & Jennifer Moore-Mallinos & Marta Fabrega & $\begin{array}{l}\text { TÜBİTAK Popüler } \\
\text { Bilim Kitapları }\end{array}$ & $6+$ \\
\hline Cem'in disleksi hikayesi & Helena Kralic & Maja Lubi & $\begin{array}{l}\text { TÜBİTAK Popüler } \\
\text { Bilim Kitapları }\end{array}$ & $5+$ \\
\hline Mantova'nın cüceleri & Gianni Rodari & $\begin{array}{l}\text { Margherita } \\
\text { Micheli }\end{array}$ & Yapı Kredi Yayınları & Belirtilmemiş \\
\hline İçimdeki aslan & Kristien Dieltiens & Klompmaker & Yap1 Kredi Yayınları & Belirtilmemiş \\
\hline Hayal satıcısı & Muhenned Al-Aküs & $\begin{array}{l}\text { Agata } \\
\text { Wojakowska }\end{array}$ & Nar Çocuk & Belirtilmemiş \\
\hline
\end{tabular}

\section{İçerik Analizi ve Kodlamalar}

Analizin ilk basamağını okul öncesi dönem çocukları için tavsiye edilen resimli öykü kitaplarının belirlenmesi oluşturmuştur. Kitap listesinde yer alan eserlerin incelenmesinde Dyches ve Prater (2000) tarafindan geliştirilen değerlendirme ölçeğindeki temel başlıklardan (Rating Scale for Quality Characterizations of Individuals with Disabilities in Children's Literature) yararlanılmıştır. Dyches ve Prater tarafından geliştirilen bu ölçek genel edebiyat standartlarının yanı sıra özel gereksinimli bireylerin betimlenmesine dayandığı için bu 
araştırmada kullanılması uygun bulunmuştur. Ölçek, özel gereksinim temalı çocuk kitaplarını; (a) özel gereksinimli bireyin karakter betimlemesi, (b) karakterlerin, özel gereksinimi olan ve olmayan diğer bireylerle ilişkisi, (c) özel gereksinimli birey ve diğer bireylerdeki değişim ve (d) özel gereksinime yönelik özel konular olmak üzere 4 tema altında inceleme firsatı sunmaktadır. Aynı zamanda ölçek kapsamında özel gereksinimli bireylerin karakter tasvirleri, sosyal ilişkileri, örnek uygulamaları ve varsa kardeș ilişkileri edebî ve sanatsal unsurlarla birlikte yapılmaktadır (Dyches \& Prater, 2005; Dyches vd., 2001; Dyches vd., 2009). Mevcut çalışmada özel olarak okul öncesi dönem çocuklarına yönelik yayımlanan kitaplar ele alındığı ve bu kitaplarda konu olarak yaş grubuna uygunluk ön planda tutulduğu için (d) özel gereksinime yönelik özel konular teması kullanılmamıştır.

Özel gereksinimli bireylerin karakter betimlemeleri için Dyches vd. (2001) ve Dyches ve Prater (2005) tarafından belirlenen kurgu, tasvir ve karakter gelişimi kodları kullanılmıştır. Mevcut çalışmada kurgu gerçekçi, yarı gerçekçi ve gerçek dışı kodları ile ifade edilmiştir. Gerçekçi kurgu ile kurgulanmış eserlerde özel gereksinimli bireyler öngörülen yetenek seviyelerine uygun bilgi ve beceri sergilemektedir. Yarı gerçekçi kurgu türünde özel gereksinimli bireylerden beklenen bilgi ve beceri seviyeleri arttırılmakta, gerçek dışı kurgularda ise karakterler olağanüstü beceriler sergilemektedir. Karakterlerin tasviri için geliştirilen kodlar ise olumlu ve nötr tasvirlerdir. Olumlu tasvirler; (a) özel gereksinimli bireyler için yüksek beklentiler öngörülen, (b) olumlu katkıların göz önüne çıkarıldığı, (c) güçlü yönlerin geliştirildiği, (d) bireylerin seçimlerinin ön plana çıkarıldığı̆, (e) diğer bireylerle gelişen karşılıklı ilişkilerin tasvir edildiği, (f) özel gereksinimli bireylerin diğer bireylerle eşit vatandaşlık haklarına sahip olduğunun garanti edildiği betimlemelerdir. Nötr tasvirlerde herhangi bir özellik öne çıkarılmamaktadır. Karakterler arası iliş̧iler teması altında kullanılan kodlar (a) birincil ilişkiler, (b) mağdur, suçlu ya da koruyucu ilişkisi, (c) bağımlı ve bakıı ilişkisi, (d) arkadaşlık, (e) öğrenci ve öğretmen ilişkisi, (f) birliktelikten kaçınma ve (g) suçluluk hissetmedir. Karakter gelişimine ait kodlar devinimsel ve durağan olarak belirtilmiştir. Devinimsel karakter gelişimi karakterin sürekli olarak bilgi ve beceri açısından gelişim gösterdiğini ifade ederken durağanda herhangi bir ilerleme söz konusu değildir (Dyches \& Prater, 2000). Çalışma sırasında belirlenen kodlarla ilgili ayrıntılı bilgiler bulgular kısmında örneklerle desteklenmiştir.

\section{Kodlama Güvenirliği}

Çalışmada yer alan araştırmacılar Türkçe eğitimi, özel eğitim ve okul öncesi eğitimi alanında çalışmaları olan uzmanlardır. Kitapların incelenmesi ve kodlanması sürecinde bütün araştırmacılar aktif olarak görev almış̧ır. Eserlerin belirlenmesi sürecinde incelenen 30 kitap her bir araştırmacı tarafından okunmuş ve kitap listesinde yer alacak 20 kitap ortak görüş bildirilerek belirlenmiştir. Kitap listesine dâhil edilen kitapların tümü, her bir araştırmacı tarafından diğer araştırmacılardan bağımsız bir şekilde okunmuş ve içerik analizi yapılmıştır. Araştırmacıların analiz sonuçları her bir kitap için belirlenen temalar altında karşılaştırılmıştır. Görüş ayrıllğı yaşanan durumlarda kitaplar araştırmacılar tarafından yeniden gözden geçirilmiş, görüş ayrıllğı yaratan durumlar tartı̧̧ılmış ve görüş birliğine varılmıştır. Karşılaştırma sonrası kodlama güvenirliği hesaplanmıştır. Kodlama güvenirliği hesaplanırken "Uzlaşılan kod sayısı / (Uzlaşılan kod sayısı + Uzlaşılamayan kod sayısı) X 100" (Kazdin, 2011, s. 104) formülü kullanılmıştır.

Bu çalışmada incelenen 20 kitabın başlangıçtaki kodlayıcılar arası güvenirliği \%80 (ranj = 76-92) olarak hesaplanmıştır. Araştırmacılar farklılıklar konusundaki görüşlerini bildirdikten sonra kodlama güvenirliği tekrar hesaplanmış ve güvenirlik \%100 olarak bulunmuştur.

\section{Bulgular}

\section{Özel Gereksinimli Bireylerin Karakter Betimlemesi}

Özel gereksinimli bireylerin karakter betimlemesi, bireyin kişisel özellikleri, karakter özelliği, tasvir, kurgu, karakter gelişimi, hikâye anlatımında kullanılan bakış açısı ve aile özellikleri açısından ele alınmış, elde edilen bilgiler Tablo 2'de belirtilmiştir. 
Tablo 2

Incelenen Kitaplar ve Karakterler

\begin{tabular}{|c|c|c|c|c|c|c|c|}
\hline Kitap ismi & Karakter & Kişisel özellikler & $\begin{array}{l}\text { Karakter } \\
\text { özelliği }\end{array}$ & Kurgu & Tasvir & $\begin{array}{l}\text { Karakter } \\
\text { gelişimi }\end{array}$ & $\begin{array}{c}\text { Bakış } \\
\text { açıs1 }\end{array}$ \\
\hline $\begin{array}{l}\text { Yağmur adam ve en } \\
\text { güzel dans }\end{array}$ & Belirtilmemiş & $\begin{array}{l}\text { İşitme yetersizliği olan } \\
\text { bir k1z çocuk }\end{array}$ & $\begin{array}{l}\text { Ana } \\
\text { karakter }\end{array}$ & $\begin{array}{l}\text { Gerçek } \\
\text { dişı }\end{array}$ & Nötr & Durağan & Üçüncü kişi \\
\hline Kreşendo & Milo & $\begin{array}{l}\text { İşitme yetersizliği olan } \\
\text { bir erkek }\end{array}$ & $\begin{array}{l}\text { Ana } \\
\text { karakter }\end{array}$ & $\begin{array}{l}\text { Yar1 } \\
\text { gerçekçi }\end{array}$ & Olumlu & Devinimsel & Üçüncü kişi \\
\hline Farklı ama aynı & Keçi & $\begin{array}{l}\text { Bedensel yetersizliği } \\
\text { olan bir keçi }\end{array}$ & $\begin{array}{l}\text { Ana } \\
\text { karakter }\end{array}$ & $\begin{array}{l}\text { Yarı } \\
\text { gerçekçi }\end{array}$ & Olumlu & Devinimsel & Üçüncü kişi \\
\hline $\begin{array}{l}\text { Şuşu, Can ve } \\
\text { Dörtteker }\end{array}$ & Can & $\begin{array}{l}\text { Bedensel yetersizliği } \\
\text { olan bir erkek çocuk }\end{array}$ & $\begin{array}{l}\text { Ana } \\
\text { karakter }\end{array}$ & Gerçekçi & Nötr & Durağan & Üçüncü kişi \\
\hline Riki'nin yeni dünyası & Riki & $\begin{array}{l}\text { Görme yetersizliği olan } \\
\text { bir erkek }\end{array}$ & $\begin{array}{l}\text { Ana } \\
\text { karakter }\end{array}$ & $\begin{array}{l}\text { Yarı } \\
\text { gerçekçi }\end{array}$ & Olumlu & Devinimsel & Üçüncü kişi \\
\hline $\begin{array}{l}\text { Down sendromlu bir } \\
\text { arkadaşım var }\end{array}$ & Tammy & $\begin{array}{l}\text { Down sendromlu 8-9 } \\
\text { yaşlarında bir kız }\end{array}$ & $\begin{array}{l}\text { Ana } \\
\text { karakter }\end{array}$ & Gerçekçi & Olumlu & Devinimsel & $\begin{array}{l}\text { Tammy'nin } \\
\text { arkadaşı }\end{array}$ \\
\hline $\begin{array}{l}\text { Dostluk engel } \\
\text { tanımaz }\end{array}$ & Dünya & $\begin{array}{l}\text { Fiziksel yetersizliği olan } \\
\text { bir k1z çocuk }\end{array}$ & $\begin{array}{l}\text { Ana } \\
\text { karakter }\end{array}$ & Gerçekçi & Olumlu & Devinimsel & Üçüncü kişi \\
\hline Barış'ın gezintisi & Barış & Otizmli bir erkek çocuk & $\begin{array}{l}\text { Ana } \\
\text { karakter }\end{array}$ & Gerçekçi & Nötr & Durağan & $\begin{array}{l}\text { Sevgi } \\
\text { (Barışın } \\
\text { kardeşi) }\end{array}$ \\
\hline $\begin{array}{l}\text { Berke'nin down } \\
\text { sendromu hikâyesi }\end{array}$ & Berke & $\begin{array}{l}\text { Down sendromlu bir } \\
\text { erkek çocuk }\end{array}$ & $\begin{array}{l}\text { Ana } \\
\text { karakter }\end{array}$ & Gerçekçi & Olumlu & Devinimsel & $\begin{array}{l}\text { Yasemin } \\
\text { (Berke'nin } \\
\text { annesi) }\end{array}$ \\
\hline Gülümsemek iyidir & Belirtilmemiş & $\begin{array}{l}\text { İşitme yetersizliği olan } \\
\text { bir erkek }\end{array}$ & $\begin{array}{l}\text { Ana } \\
\text { karakter }\end{array}$ & Gerçekçi & Olumlu & Durağan & Mimi \\
\hline Mantova'nın cüceleri & Cüceler & Çok sayıda cüce insan & $\begin{array}{l}\text { Ana } \\
\text { karakter }\end{array}$ & $\begin{array}{l}\text { Gerçek } \\
\text { diş1 }\end{array}$ & Olumlu & Devinimsel & Üçüncü kişi \\
\hline Greg'in zaferleri & Greg & $\begin{array}{l}\text { Konuşma bozukluğu } \\
\text { olan anaokulu çağında } \\
\text { bir erkek çocuk }\end{array}$ & $\begin{array}{l}\text { Ana } \\
\text { karakter }\end{array}$ & Gerçekçi & Olumlu & Devinimsel & Üçüncü kişi \\
\hline Zoe zor öğreniyor & Zoe & $\begin{array}{l}\text { Zihin yetersizliği } \\
\text { bulunun bir k1z }\end{array}$ & $\begin{array}{l}\text { Ana } \\
\text { karakter }\end{array}$ & Gerçekçi & Nötr & Devinimsel & Üçüncü kişi \\
\hline Cem'in disleksisi var & Cem & $\begin{array}{l}\text { Disleksisi olan erkek bir } \\
\text { çocuk }\end{array}$ & $\begin{array}{l}\text { Ana } \\
\text { karakter }\end{array}$ & Gerçekçi & Olumlu & Durağan & Cem \\
\hline Bende disleksi var & Sarah & $\begin{array}{l}\text { Disleksisi olan bir k1z } \\
\text { çocuk }\end{array}$ & $\begin{array}{l}\text { Ana } \\
\text { karakter }\end{array}$ & Gerçekçi & Olumlu & Devinimsel & Sarah \\
\hline Yapabilirim & Adrian & $\begin{array}{l}\text { Fiziksel yetersizliği olan } \\
\text { bir erkek çocuk }\end{array}$ & $\begin{array}{l}\text { Ana } \\
\text { karakter }\end{array}$ & Gerçekçi & Olumlu & Devinimsel & Adrian \\
\hline $\begin{array}{l}\text { Bir türlü yerimde } \\
\text { duramıyorum }\end{array}$ & Lukas & $\begin{array}{l}\text { DEHB olan bir erkek } \\
\text { çocuk }\end{array}$ & $\begin{array}{l}\text { Ana } \\
\text { karakter }\end{array}$ & Gerçekçi & Olumlu & Devinimsel & Lukas \\
\hline $\begin{array}{l}\text { Duymamak böyle bir } \\
\text { şey }\end{array}$ & Lana & $\begin{array}{l}10 \text { yaşında işitme } \\
\text { yetersizliği olan bir k1z }\end{array}$ & $\begin{array}{l}\text { Ana } \\
\text { karakter }\end{array}$ & Gerçekçi & Olumlu & Devinimsel & Lana \\
\hline İçimdeki aslan & Vaut & $\begin{array}{l}\text { DEHB olan bir erkek } \\
\text { çocuk }\end{array}$ & $\begin{array}{l}\text { Ana } \\
\text { karakter }\end{array}$ & Gerçekçi & Olumlu & Durağan & Üçüncü kişi \\
\hline Hayal saticisı & Belirtilmemiş & $\begin{array}{l}\text { İki çocuk annesi } \\
\text { ortopedik yetersizliği } \\
\text { olan bir kadın }\end{array}$ & $\begin{array}{l}\text { Yan } \\
\text { karakter }\end{array}$ & Gerçekçi & Nötr & Durağan & $\begin{array}{l}\text { Kadının } \\
\text { oğlu }\end{array}$ \\
\hline
\end{tabular}



INCELENMESI

İncelenen 20 resimli öykü kitabında toplamda 20 özel gereksinimli bireyden $(n=20)$ bahsedilmiştir. Karakter sayıları hesaplanırken çok sayıda cüce bireyin hikâyesinin anlatıldığı 'Mantova'nın Cüceleri' kitabındaki cüce karakter sayısı eserde belirtilmediği için 1 olarak belirtilmiştir. İncelenen 20 özel gereksinimli bireyin sadece $1(n=1)$ tanesi 'Farklı Ama Aynl' kitabında hayvan karakter olarak yer alırken geri kalan $19(n=19)$ karakter farklı yaşlardaki insanlardan oluşmaktadır. Özel gereksinimli bireylerin yaş grubu yeni doğan bir erkek çocuğundan iki çocuk annesi yetişkin bir kadına kadar geniş bir aralıktadır. Karakterlerin cinsiyetlere göre dağılımı ise yine 'Mantova'nın Cüceleri' kitabında hem erkek hem kız karakterler olduğu için 9 kız (\%45), 12 erkek (\%55) bireyden oluşmaktadır ve kitapların tümünde karakterlerin cinsiyeti belirtilmiştir.

İncelenen 20 kitabın 6'sında fiziksel yetersizlik (\%30), 4'ünde işitme yetersizliği (\%20), 3'ünde zihin yetersizliği (\%15), 2'sinde disleksi (\%10), 2'sinde dikkat eksikliği ve hiperaktivite bozukluğu (\%10), 1'inde görme yetersizliği (\%5), 1'inde otizm (\%5), 1'inde ise konuşma bozukluğu (\%5) konu edilmiştir. Fiziksel yetersizliğin konu edildiği kitapların 5'inde özel gereksinimli bireyler yürüme yetersizliği (\%84) olan bireylerken, 1'inde (Mantova'nın Cüceleri) özel gereksinimli bireyler cücelerdir (\%16). Zihin yetersizliğinin konu edildiği kitaplarda Down Sendromu $(n=2)$ ve hafif düzeyde zihinsel yetersizliği $(n=1)$ olan bireylerin hikâyeleri anlatılmaktadır. Sadece bir kitapta $(n=1)$ otizmli bir karakterin hikâyesi anlatılmıştır.

Kitapların 17'sinde (\%85) özel gereksinimler açık şekilde belirtilirken 3 kitapta (\%15) özel gereksinimler isimlendirilmemiştir. Örneğin 'Hayal Satıclsl' kitabında fiziksel yetersizliğe sahip annenin özel gereksinimleri ifade edilmeden sadece tekerlekli sandalyeye ihtiyaç duyduğu belirtilmiştir. Farklı özel gereksinimlerin konu edildiği kitaplarda farklı yetersizlikleri bulunan bireylerin ihtiyaç durumları da değişmektedir. Kitapların 5'inde (\%25) özel gereksinimli bireyler herhangi bir yardıma ihtiyaç duymazken, diğer 15 kitapta (\%75) özel gereksinimli bireyler yardıma ihtiyaç duymakta ve ihtiyaç düzeyleri hafiften ağır düzeye kadar değişmektedir. Örneğin 'Kreşendo' kitabında işitme yetersizliği olan Milo anneannesinden sesi tanımlayabilmesi için hafif şekilde bir yardım alırken, özellikle ağır düzeyde yetersizliği bulunan bireyler yoğun şekilde yardıma ihtiyaç duymaktadır. Örneğin, 'Barış'ın Gezintisi' kitabında Barış otizmli olduğu için ablası Sevgi'nin desteği olmadan dışarıya çıkamamakta, hatta ablaları yanında olmasına rağmen bir süre onların gözetiminden ayrılan Barış’ın kaybolduğu görülmektedir. Ayrıca özel gereksinimli bireylerin kullandığı yardımcı materyaller de incelenmiş, kullanılan materyaller arasında tekerlekli sandalye ('Farklı ama Aynı' kitabında çoban keçi için tekerlekli sandalye niteliğinde özel bir araç geliştirmiştir), gözlük ve rehber köpek olduğu görülmüştür.

Kitaplar bir diğer tema olan kurgu açısından incelendiğinde, sonuçlar kitapların büyük kısmında gerçekçi kurgunun uygulandığını $(n=15$ veya \%75) göstermiştir. Kitapların 5'inde ise özel gereksinimli karakterlerin yetenekleri ve başlarından geçen olaylar kurguyu yarı gerçekçi (\%25) hale getirmiştir. Gerçekçi kurguya sahip kitaplarda özel gereksinimli karakterler kendilerinden beklendik düzeyde ve özel gereksinimlerine uygun beceriler sergilemektedir. Örneğin 'Greg'in Zaferleri' kitabında Greg konuşma becerisinde yaşıtları ile aynı düzeyde olmamasına rağmen çok başarılı resimler çizebilmekte ve tekvando alanında kendini geliştirebilmektedir. Gerçek dışı kurgulardan biri olan 'Riki'nin Yeni Dünyası' kitabında görme yetersizliği olan Riki evden çıkıp kaybolduğunda rehber köpeğinin sırtına binerek şehri gezmektedir. Benzer şekilde 'Yağmur Adam ve En Güzel Dans' kitabında Yağmur Adam adlı düşsel bir karakterin olması ve işitme yetersizliği olan küçük kızın Yağmur Adam'la konuşup onu tekrar yağmur yağdırmaya ikna etmesi, eseri gerçekçi kurgunun dışına çıkarmıştır.

Yapılan analizler sonucunda, incelenen kitapların 14'ünde (\%70) özel gereksinimli karakterlerin olumlu tasvir edildiği ortaya çıkmıştır. İncelenen kitapların 6'sında (\%30) ise özel gereksinimli karakterler için olumlu tasvir söz konusu değildir. Olumlu tasvirin en çok öne çıktığı kitaplardan biri olan 'Berke'nin Down Sendromu Hikâyesi' kitabında Berke doğduğu günden itibaren bütün ailenin neşelenmesine sebep olan, esprileri ve yardımları ile ailenin diğer üyelerine katkıda bulunan, diğer aile bireyleri ile eşit haklara sahip bir birey olarak tanımlanmıştır. Kitapta Berke'nin özellikle güçlü yönleri, diğer karakterlere olumlu katkıları ve sürekli gelişen ilişkileri ön plana çıkarılmıştır. Söz gelimi Berke resim çizebilmekte, şarkı söylemeyi sevmektedir. Kendisi giyinebilmekte, yemeğini yiyip ayakkabılarını bağlayabilmektedir. Annesinin desteğiyle okuma yazmayı da öğrenmiştir. Hatta bir gün annesine "Beni dünyaya getirdiğin için teşekkür ederim." demiştir. Bu onun kurduğu yakın ilişkilerden yalnızca bir tanesidir. 'Yapabilirim' kitabında da Adrian fiziksel yetersizliğinin diğer arkadaşlarından geride kalmasına sebep olmaması için azim göstermiş ve diğer arkadaşları gibi pek çok etkinliğe katılmış, gösterdiği çaba sayesinde okulun basketbol takımına seçilmiştir. Kitapta özellikle Adrian'ın azim ve kararlıllığ ile birçok zorluğun üstesinden geldiğginin ve etrafındaki insanların ondan ve tekerlekli sandalyesinden korkmaması gerektiğinin altı çizilmiştir. Özel gereksinimli bireylerin kendilerinden olan yüksek beklentilerinin en çok öne çıktığı kitap 'Yapabilirim' olmuştur. Bu, Adrian'ın kitabın sonuna doğru söylediği şu sözlerden 
anlaşılabilir: "Tekerlekli sandalyede olmam artık önemli değil. Başka çocukların yapabildiği hemen her şeyi yapabileceğimi biliyorum, bu da bana mutluluk veriyor. Okuldaki basketbol takımına bile girdim."

Olumlu tasvirin kullanıldığı diğer kitaplar arasında 'Farklı Ama Aynı' kitabı da yer almaktadır. İnsan dışı bir özel gereksinimli karakterin anlatıldığı kitapta fiziksel yetersizliği olan bir keçi hem diğer keçiler gibi hayatına devam etmekte, yavrulamakta hem de diğer keçilere yardım ederek ailesine ve çevresine katkıda bulunmaktadır. 'Down Sendromlu bir Arkadaşım Var' kitabında ise Down sendromlu Tammy'nin müziğe olan yeteneği ön plana çıkarılmış ve diğer arkadaşları ile eşit haklara sahip olduğu, katıldı̆̆ı yetenek yarışması ile vurgulanmıştır. Tammy arkadaşlarını da cesaretlendirerek yarışmaya katılmış ve gitar çalarak yeteneklerini sergileme olanağı bulmuştur.

Olumlu tasvirin kullanılmadığı kitaplardan biri özel gereksinimli karakterin çoğunlukla zayıf yönlerinin sergilendiği 'Iç̧imdeki Aslan' kitabıdır. Dikkat eksikliği ve hiperaktivite bozukluğu olan Vaut; ev ortamında oluşturduğu düzensizlik, aşırı fiziksel aktiviteler ve aile bireyleri ile arasındaki olumsuz ilişkiyle ön plana çıkmaktadır. Mesela sabah çok erken saatlerde uyanarak evde şiddetli gürültüler çıkarmış, kardeşinin kitabını yırtmış birtakım tepkilerle karşılaşmıştır. Kitaptan alınan şu cümleler Vaut'un bu davranışlarını örneklendirmektedir: "Buldum, bomba yapacağım. Hem de aptal kızın kitabından yapacağım sayfalarla!' dedi gülerek. Suzan'ın kitabından birkaç sayfa kopardı, sayfaları buruşturup büyük kâğıt toplar yaptı... O sırada kapı açıldı. Gelen üzerinde pijamalarıyla babasıydı. Gözlerinde şimşekler çakıyordu” (Dieltiens, 2019, s. 11). Benzer şekilde 'Zoe Zor Ögrreniyor' kitabında da Zoe zihin yetersizliğinden dolayı aile bireyleri ile olumsuz ilişkiler kurmakta, gittiği okulda kurallara uyamamakta, yönergeleri yerine getiremeyip ceza almaktadır ve Zoe'nin genellikle olumsuz özellikleri vurgulanmaktadır. Kitaplar, anlatııı bakış açısı bağlamında incelendiğinde en çok tercih edilen bakış açısının üçüncü kişi bakış açısı (\%50) olduğu, sadece 5 kitabın özel gereksinimli bireyin gözünden (\%25) anlatıldığı, kalan kitaplarda ise özel gereksinimli bireylerin yakın arkadaşları ve aile bireylerinin (\%25) anlatıcı olarak kullanıldığı görülmektedir.

Kitaplarda tasvir edilen aile yapıları çeşitlilik göstermekle birlikte çoğunlukla anne, baba ve kardeşlerin varlı̆ı̆ından bahsedilen çekirdek aile yapısı (\%45) kullanılmıştır. İncelenen kitapların 7'sinde ailelerden bahsedilmemiş (\%35) diğer kitaplardan 1'inde sadece anneden (\%5), kalan kitaplarda ise teyze, amca, anneanne gibi aile bireylerinden oluşan geniş aileler $(\% 15)$ betimlenmiştir.

\section{Karakterlerin Özel Gereksinimi Olan ve Olmayan Karakterler ile İlişkisisi}

İnceleme sonuçlarından hareketle kitaplar içerisinde yer alan özel gereksinimi olan ve olmayan bireyler arasındaki ilişkiler altı farklı alt tema altında toplanmıştır; (a) birincil ilişkiler, (b) mağdur, suçlu ya da koruyucu ilişkisi, (c) bağımlı ve bakıcı ilişkisi, (d) arkadaşlık, (e) öğrenci ve öğretmen ilişkisi ve (f) birliktelikten kaçınma. Daha önce yapılan çalışmalarda (Dyches vd., 2001) yedinci bir ilişki türü olan suçluluk hissetme de çalışmalara dahil edilmiş, fakat mevcut çalışmada incelenen kitaplarda bu ilişki türüne örnek bulunamamıştır.

Sonuçlara göre incelenen kitaplardaki toplam 33 ilişki arasında en sık görülen iki tür ilişki, öğrenciöğretmen $(n=9, \% 27)$ ve bağımlı-bakıcı $(n=9, \% 27)$ ilişkisidir. Öğrenci-öğretmen ilişkisi, yalnızca okul ortamında gerçekleşen öğretim sürecini değil evde ya da dış ortamlarda toplumun diğer kesimleriyle kurulan ilişkiler sonucunda öğrenilen yetenekleri ve bilgi alışverişini de kapsamaktadır. İncelenen kitaplardaki öğrenciöğretmen ilişsilerinin büyük kısmı okul ortamında gerçekleşse de 'Riki'nin Yeni Dünyası' kitabında Riki anneannesinin yardımı ile Braille alfabesini öğrenmektedir. Okul ortamı dışındaki öğrenci-öğretmen ilişkilerinde öğretmen görevini özel gereksinimli bireyin yaşıtları, anne ve babalar ve kardeşleri de üstlenmektedir. Bu ilişki türünün görüldüğü tüm kitaplarda özel gereksinimli bireyler öğrenci rolündedir.

Bağımlı-bakıcı ilişkisi; bakıcı görevini genellikle özel gereksinimli bireyin en yakın olduğu karakterin üstlendiği ilişkilerdir. Bağımlılık derecesi tam bağllıktan daha az bağımlılığa kadar değişiklik göstermektedir. Daha az bağımlılığın en belirgin örneklerinden biri olan 'Berke'nin Down Sendromu' hikâyesinde yeni doğan Berke'nin bütün ihtiyaçlarını annesi karşılarken, Berke'nin yaşı büyüdükçe bağımlılık derecesi azalmıştır. Bakıcı görevini çoğunlukla tipik gelişim gösteren karakterlerin üstlendiği görülse de 'Hayal Satıcısı' kitabında ismi verilmeyen özel gereksinimli karakter olan anne çocuklarının bakım görevini sürdürmektedir.

En sık görülen ikinci ilişki türü ise arkadaşlıktır $(n=7, \% 21)$. İncelenen kitaplardaki arkadaşlık ilişkilerinin tümü özel gereksinimi olan bir karakter ile özel gereksinimi olmayan bir karakter arasında kurulmuştur. 'Dostluk Engel Tanımaz' kitabında olduğu gibi bazı kitaplarda özel gereksinimli birey birden fazla arkadaşlık ilişkisi kurabilmektedir ve bu ilişkiler öncesinde birliktelikten kaçınma ilişkisi içerirken sonrasında 
arkadaşlığa dönüşmüştür. Arkadaşlık ilişkilerini birincil ilişkilerden ayıran ise karşılıklı ve olumlu ilişkiler olmasidır.

Mağdur, suçlu ya da koruyucu ilişkileri $(n=4, \% 12)$ ise üçüncü sırada yer almaktadır. Mağdur, suçlu ya da koruyucu ilişkileri genellikle özel gereksinimli bireylerin mağdur, tipik gelişim gösteren bireylerin ise suçlu ve koruyucu rolünde olduğu ilişkiler olmasına rağmen incelenen iki kitapta özel gereksinimli bireylerin suçlu rolünde de olduğu görülmektedir. Örneğin 'Zoe Zor Öğreniyor' kitabında öğrenme güçlüğü olan Zoe, kız kardeși ve evdeki diğer bireylere davranış problemleri ile zarar vermektedir. Diğer tarafta 'Mantova'nın Cüceleri' kitabında önceki çalışmalara uygun olarak cüceler mağdurken, tipik gelişim gösteren bireylerin suçlu olduğu görülmektedir. Son olarak en nadir görülen ilişki türlerinin birincil ilişsiler $(n=2, \% 6)$ ve birliktelikten kaçınma $(n=2, \% 6)$ olduğu belirlenmiştir.

\section{Özel Gereksinimli Birey ve Diğer Bireylerdeki Değişim}

Bir diğer içerik analizi ise karakterlerin gelişimi üzerine yapılmıştır. Karakter gelişimleri devinimsel ya da durağan olarak kategorize edilmiştir. Devinimsel karakter gelişimi, gelişen ve ilerleyen karakterleri temsil ederken durağan karakterlerde gelişim görülmez. İncelenen kitapların 13'ünde devinimsel karakter gelişimi (\%65) görülürken, 7'sinde durağan karakter gelişimi (\%35) görülmektedir. Devinimsel karakter gelişimi bazı kitaplarda çok açık bir şekilde görülürken bazı kitaplarda örtük bir şekilde anlatılmaktadır. Örneğin 'Riki'nin Yeni Dünyası' kitabında hikâyenin başlangıcında görme yetersizliği olan Riki sessiz ve tek başına odasında otururken, kitabın sonunda anneannesi ile birlikte Braille alfabesini öğrenmekte ve kitap okumaktadır. Kitabın tümünde Riki’nin devinimsel gelişimi açık bir şekilde ortaya konmaktadır. 'Barış'ın Gezintisi' kitabında ise karakter tam olarak durağan bir karakterdir. Gün boyunca ablaları ile gezintide olan otizmli Barış, herhangi bir ilerleme ve gelişim göstermemektedir.

\section{Tartışma}

Resimli öykü kitapları okul öncesi dönemde özel gereksinim ile ilgili eğitim ve bilgilendirme amaçlı kullanılabilecek araçlardan biridir. Bu çalışmada 20 okul öncesi döneme uygun resimli öykü kitabının özel gereksinimli karakterler bağlamında bir içerik analizi sunulmuştur. Özellikle, Dyches ve Prater $(2000 ; 2005)$ ve Dyches ve diğerlerinin (2001) çalışmaları örnek alınarak özel gereksinimli bireylerin kitaplardaki karakter betimlemesi ve tipik gelişim gösteren karakterler ile olan ilişkileri incelenmiştir. Bu bölümde, bu çalışmanın sonunda elde edilen sonuçlar tartışılmış ve gelecek çalışmalar için önerilerde bulunulmuştur.

Bu çalışma kapsamında incelenen 20 okul öncesi dönem çocuklarına uygun resimli öykü kitabında altı farklı özel gereksinim durumu tespit edilmiştir. Kitaplarda yer alan karakterlerin yaygın olarak fiziksel yetersizliğe (6 kitap), zihin yetersizliğine (4 kitap) ve işitme yetersizliğine (4 kitap) sahip oldukları bulunmuştur. Bu inceleme sonucunda okul öncesi kitaplarda özel gereksinim durumunun karakterlerin dışarıdan gözlenebilen özelliklerine vurgu yapılarak belirtildiği görülmektedir. Ancak özel öğrenme güçlükleri (ör. disleksi) ve dikkat eksikliği ve hiperaktivite bozukluğu gibi yaygınlık oranı fazla olan özel gereksinim durumları hakkında az sayıda resimli öykü kitabı olduğu görülmektedir. Ayrıca üstün zekâ/yetenek konusu hakkında da herhangi bir resimli öykü kitabı tespit edilememiștir. Bu durumun okul öncesi çocuklarında özel gereksinim durumunun sadece karakterlerin dıșarıdan gözlenebilen (ör. karakterlerin tekerlekli sandalye kullanımı, işaret dili kullanımı, baston ve gözlük kullanımı, Down Sendromlu olmak gibi) özellikleri ile ilgili olduğu şeklinde hatalı bir düşünceye sebep olabileceği düşünülmektedir. İncelenen kitaplar genel olarak özel gereksinim durumları ile ilgili bir çeşitlilik sunmaktadır. Bu durum, örneğin Newbery Ödülü Kazanan Kitaplar'ın incelendiği bir çalıșmada bulunan sonuçlar ile benzerlik göstermektedir (Leininger vd., 2010). Leininger ve meslektaşları (2010) Amerika Birleşik Devletleri'nde tanımlanan 13 özel eğitim kategorisinden 12'sine kitaplarda yer verildiğini bulmuştur. Karakterlerin çoğunlukla ortopedik yetersizlik, duygu/davranış bozuklukları ve zihin yetersizliğine sahip olduğu bulunmuştur. Ancak öğrenme güçlüğü ve dil ve konuşma bozuklukları okul çağındaki özel gereksinimli öğrenciler arasında oldukça yaygın olmasına rağmen, bu özelliklere sahip az sayıda karakter bulunmuştur.

Bu kitapların okul öncesi çocuklara sunumu sırasında karakterlerin özellikleri ve özel gereksinimli öğrencilerin gerçek yaygınlık oranları arasında bir orantı olmasına dikkat edilmesi gerekir çünkü kitaplar aracılı̆̆ı ile çocuklar gerçek yaşam durumlarına hazırlanacaklarsa karşılaşmaları daha olası durumlara dair deneyimler edinmeleri daha makul olacaktır (Dyches, vd., 2006; Leininger vd., 2010). Bu çalı̧̧madaki toplam 14 kitapta özel gereksinimli karakterin olumlu tasviri yapılmıştır. Olumlu tasvirlerin kodlanmasında şu kategoriler kullanılmıştır (Dyches vd., 2001): (a) özel gereksinimli bireyler için yüksek beklentilerin öngörüldüğü, (b) olumlu katkıların göz önüne alındığı, (c) güçlü yönlerin geliştirildiğĭ, (d) bireylerin seçimlerinin ön plana çıkarıldığı, (e) diğer bireylerle 
gelişen karşılıklı ilişkilerin tasvir edildiği ve (f) özel gereksinimli bireylerin diğer bireylerle eşit vatandaşlık haklarına sahip olduğunun garanti edildiği betimlemeler. Fakat incelenen kitapların okul öncesi döneme ait olması ve kitaplardaki özel gereksinimli karakterlerin büyük bir bölümünün erken çocukluk döneminde olması sebebiyle beklentiler, topluma olumlu katkılar, güçlü yönler, karakterin seçimleri ve sahip oldukları haklar bu yaş grubuna göre değerlendirilmiştir. Bu yüzden olumlu tasvirin yapılmadığı tespit edilen altı çalışmada yaş grubunun özelliklerinin topluma katkıyı doğal bir biçimde sınırlandırdığı görülmektedir. Bu yaşta olan ve özel gereksinim durumu olmayan çocukların da vatandaşı olarak içinde yaşadığı topluma sınırlı katkılarda bulunabileceği -söz gelimi oy kullanamayacağı, dilekçe yazamayacağı, kamu kurum ve kuruluşlarıyla ilişkisinin sınırlı olacağıkitapların değerlendirilmesi sırasında göz önünde bulundurulmuştur.

Bu çalışmanın bir başka sonucuna göre incelenen 15 kitabın gerçekçi ve 5 kitabın yarı gerçekçi kurguya sahip olduğu belirlenmiştir. Gerçekçi kurguya sahip kitaplarda özel gereksinimli karakterlerin var olan potansiyellerinin ayrıntılı bir betimlemesi yapılmıştır. Bende Disleksi Var, Down Sendromlu Bir Arkadaşım Var, Barış'ın Gezintisi ve Zoe Zor Öğreniyor kitaplarındaki kurgular karakterlerin gerçek özelliklerinin sergilendiği durumlara örnek olarak gösterilebilir. Bu noktada son 20 yılın resimli okul öncesi kitaplarında tasviri yapılan özel gereksinimli karakterler ile klasik eserlerdeki özel gereksinimli karakterlerin tasvirleri arasında anlamlı bir fark olduğu görülmektedir. Örneğin, Rubin ve Watson (1987), klasik eserlerde özel gereksinimli bireylerin çoğunlukla olumsuz ve gerçekçi olmayan özellikleri ile tasvir edildiğini belirtmektedir. Diğer taraftan bu çalışmada incelenen kitapların çoğunluğunda özel gereksinimli karakterlerin var olan potansiyellerinin gerçekçi kurgularla yansıtılması bu karakterler ile ilgili okul öncesi çocuklara doğru bir bilgi paylaşımı sağlamak açısından önemlidir. Gerçekçi ve içinde yaşanılan çağın gereklerine uygun yapılan karakter tasvirleri özel gereksinimli bireyler hakkında nitelikli çocuk edebiyatı eserleri oluşturmak için gereklidir.

Bu çalışmada incelenen 13 kitapta (\%65) özel gereksinimli karakterlerin hikâyeler boyunca devinimsel bir gelişim gösterdiği tespit edilmiştir. Sadece 7 kitapta (\%35) özel gereksinimli karakterlerin gelişimi durağan olarak bulunmuştur. Karakter gelişiminin devinimsel bir özellik göstermesi bu çalışmanın önemli bulgularından biridir. Devinimsel gelişim gösteren karakterlerin çoğunluğunun aynı zamanda gerçekçi ve olumlu tasvirlerinin birlikte yapıldığı da görülmektedir. Alanyazında yer alan çalışmalarda Dyches vd. (2001) özel gereksinimli karakterlerin sadece \%50'sinin, Dyches ve Prater (2005) ise özel gereksinimli karakterlerin \%58'inin hikâye boyunca dinamik bir gelişim gösterdiğini belirlemiştir. Bu çalışmanın sonuçları ise geçmiş çalışmalara kıyasla daha fazla (\%65) özel gereksinimli karakterin dinamik, olumlu ve gerçekçi olarak gelişim gösterdiğini ortaya koymuştur. Dyches ve Prater (2005) özel gereksinimli çocuklar için dinamik bir karakter tasvirinin kitap yazarları açısından zor bir denge durumu olduğunu belirtmiştir. Bunun nedeni ise kitap yazarının hikâye boyunca özel gereksinimli karakterin mevcut performansını ve potansiyel gelişim alanını nitelikli bir biçimde kurgulamasının gerekiyor olmasıdır. Mevcut performans ve potansiyel gelişim alanı her bir özel gereksinim durumu için bir diğerinden farklılaşabilmektedir. Bu yüzden incelenen kitaplardaki karakter gelişiminin gerçekçi beklentiler ve gelişim özellikleri ile birlikte bir denge içerisinde sunulabilmesi oldukça önemlidir.

Bu çalışmada özel gereksinimli karakterler ve diğer karakterler arasındaki ilişkiler farklı boyutlarda incelenmiştir. İncelenen kitaplarda en yaygın karakterler arası ilişki türünün özel gereksinimli karakterler ile öğretmenleri arasındaki ilişki olduğu bulunmuştur. Buna ek olarak bazı karakterlerin bağımlı-bakıcı, arkadaşlık, mağdur-suçlu ve korunmaya muhtaç-koruyucu gibi ilişsilerde de yer aldığ 1 belirtilmiştir. Bu sonuç geçmişte yapılan benzer kitap incelemesi çalışmalarından farklılık göstermektedir. Örneğin, Dyches ve Prater (2005) en yaygın karakterler arası ilişkinin özel gereksinimli karakterler ile akranları arasında olduğunu bulmuştur. Başka bir çalışmada ise Dyches ve diğerleri (2001) en yaygın karakterler arası ilişkinin özel gereksinimli karakterler ile kardeşleri arasında olduğunu belirtmiştir. Özel gereksinimli karakterlerin diğer karakterler ile kurdukları çeşitli ilişkiler kendileri hakkında oluşabilecek olası ön yargıları ortadan kaldırmak açısından önemlidir. Bu aynı zamanda gerçekçi bir tasvir yapmanın özel gereksinimli bireyler ve tipik gelişen bireylere olumlu katkı sağlayacağı anlamına gelebilecektir. Bu tür karakterler hakkında bilgi alan okul öncesi çocuklar, özel gereksinimli bireylerin çeşitli iletişim becerilerine sahip olabildiklerini ve bu becerilerini farklı ilişkileri başlatma ve devam ettirmede kullanabildiklerini öğrenme firsatlarına sahip olacaklardır.

\section{Gelecek Çalışmalar İçin Öneriler}

$\mathrm{Bu}$ çalışma kapsamında incelenen 20 resimli öykü kitabının okul öncesi dönemdeki çocuklara özel gereksinim hakkında bilgi sunmak açısından faydalı olabileceği düşünülmektedir. Mevcut kitapların bir okuma programı dâhilinde okul öncesi dönemdeki çocuklara farklı özel gereksinim konuları hakkında farkındalık kazandırmak için kullanılması önerilebilir. 
1. Okuma programlarının okul öncesi çocukların özel gereksinim konusuna yönelik davranış ve tutumları üzerindeki etkisi incelenebilir. Bununla birlikte, okul öncesi sınıflarında bu çalışmada incelenen resimli kitaplara benzer kitapların bulunup bulunmadığı ile ilgili keşfedici çalışmalar yapilabilir.

2. Gelecekte okul öncesi sınıfların kütüphanelerinde varsa özel gereksinim temalı eserler incelenerek bu eserleri betimleyici bir çalışma yapılabilir.

3. Okul öncesi döneme yönelik resimli öykü kitaplarındaki özel gereksinim durumlarının çeşitliliği, gerçek hayattaki çeşitlilikle orantılı olmalıdır. Örneğin çok yaygın olan öğrenme güçlüğü ve dil ve konuşma bozuklukları hakkında daha fazla kitap yazılabilir. Ayrıca üstün zekâlı ve özel yetenekli bireyleri konu alan eser tespit edilememiştir. Bu konuda kitaplar yazılabilir.

4. Yazar ve çizerler, okul öncesi döneme yönelik resimli öykü kitaplarındaki özel gereksinimli karakterleri, kendi doğalarına uygun özellikleriyle betimlemelidir.

5. Özel gereksinimliliği konu alan kitapların kurgusal bütünlüğü, fiziksel nitelikleri, görsellerinin ilgili yaş gruplarına uygunluğu incelenebilir.

\section{Yazarların Katkı Düzeyleri}

Araştırmanın bütün safhalarında yazarlar iş birliği hâlinde çalışmış ve eşit katkı sağlamıştır. 
*Incelemeye konu olan kitapları gösterir.

\section{Kaynaklar}

*Al-Aküs, M. (2018). Hayal satıcısı [Baea Al-Ahlam]. (A. Lale, Çev.; 2. baskı). Nar Çocuk. (Orijinal kitabın yayın tarihi 2017)

Blaska, J. (2004). Children's literature that includes characters with disabilities or illnesses. Disability Studies Quarterly, 24(1). https://dsq-sds.org/article/view/854/1029

*Cabrara, A. (2013). Riki'nin yeni dünyası [Rick and the new world]. (A. Uludağ, Çev.; 1. baskı). TÜBİTAK Popüler Bilim Kitapları. (Orijinal kitabın yayın tarihi 2011)

Cavkaytar, A. (2019). Özel eğitime gereksinim duyan çocuklar ve özel eğitim. İ. H. Diken (Ed.), Özel ĕgitime gereksinimi olan ögrenciler ve özel eğitim [Students with special needs and special education] içinde (ss. 1-29). Pegem Akademi.

Denzin, N. K., \& Lincoln Y. S. (2000). Handbook of qualitative research (2nd ed.). Sage Publication.

*Dieltiens, G. (2019). İçimdeki aslan [Le lion dans la tete de Ludovic]. (Y. Varnalı, Çev.; 7. baskı). Yapı Kredi Yayınları. (Orijinal kitabın yayın tarihi 2007)

Dyches, T. T., \& Prater, M. A. (2000). Developmental disability in children's literature: Issues and annotated bibliography. The Division on Mental Retardation and Developmental Disabilities of the Council for Exceptional Children.

Dyches, T. T., \& Prater, M. A. (2005). Characterization of developmental disability in children's fiction. Education and Training in Developmental Disabilities, 40(3), 202-216.

Dyches, T. T., Prater, M. A., \& Cramer, S. F. (2001). Characterization of mental retardation and autism in children's books. Education and Training in Mental Retardation and Developmental Disabilities, 36(3), 230-243.

Dyches, T. T., Prater, M. A., \& Leininger, M. (2009). Juvenile literature and the portrayal of developmental disabilities. Education and Training in Developmental Disabilities, 44(3), 304-317.

Ergül, C., Karaman, G., Akoğlu, G., Tufan, M., Sarıca, A. D., \& Kudret, Z. B. (2014). Okul öncesi öğretmenlerinin "erken okuryazarlık" kavramına ilişkin bilgi düzeyleri ve sınıf uygulamaları [Knowledge levels and classroom practices of preschool teachers related to the concept of "early literacy"]. Elementary Education Online, 13(4). 193-206. https://doi.org/10.17051/io.2014.71858

*Fortin, M. C. (2015). Zoe zor öğreniyor [Les difficultés de Zoé]. (Y. Varnalı, Çev.; 3. baskı). Yapı Kredi Yayınları. (Orijinal kitabın yayın tarihi 2012)

Gürdal-Ünal, A. (2014). Türk çocuk edebiyatında engellilik 1969-2009 [Disability in Turkish children's literature 1969-2009]. Evrensel Basim Yayın.

*Karakiya, Y. (2014). Şuşu, Can ve Dörtteker [Şuşu, Can, and Dörtteker]. Sev Yayıncılı.

Kaymaz, Ç. (2017). Özel gereksinimliliği içeren Türkçe ve çeviri resimli çocuk kitaplarının incelenmesi [Review of Turkish and translation children picture books including special needs] (Tez numaras1: 468855) [Yüksek lisans tezi, Hacettepe Üniversitesi]. Yükseköğretim Kurulu Ulusal Tez Merkezi.

Kazdin, A. E. (2011). Single case research designs: Methods for clinical and applied settings. Oxford University Press.

*Kralic, H. (2016a). Berke'nin down sendromu hikâyesi [Tengo síndrome de down]. (S. E. Opşin, Çev.; 3. bask1). TÜBİTAK Popüler Bilim Kitapları. (Orijinal kitabın yayın tarihi 2014)

*Kralic, H. (2016b). Cem'in disleksi hikâyesi [Tengo dislexia]. (S. E. Opşin, Çev.; 2. baskı). TÜBİTAK Popüler Bilim Kitapları. (Orijinal kitabın yayın tarihi 2015)

*Lears, L. (2016). Barış'ın gezintisi:Otizm hakkında bir öykü [Ian's walk a story about autism]. (M. Ö. Kılıç, Çev.; 8. bask1). TÜBİTAK Popüler Bilim Kitapları. (Orijinal kitabın yayın tarihi 1998) 
Leininger, M., Dyches, T. T., Prater, M. A., \& Heath, M. A. (2010). Newbery award winning books 1975-2009: How do they portray disabilities? Education and Training in Autism and Developmental Disabilities, 45(4), 583-596.

Lukens, R. J. (2002). A critical handbook of children's literature. Diane Publishing.

"Mattiangeli, S., \& Sala, F. (2017). Kreşendo [Crescendo]. (K. Atakay, Çev.; 1. bask1). Elma Çocuk. (Orijinal kitabın yayın tarihi 2015)

Milli Eğitim Bakanlığı [Ministry of National Education]. (2020). Özel Eğitim Hizmetleri Yönetmeliği. http://orgm.meb.gov.tr/meb_iys_dosyalar/2020_06/24163215_ozel_eYitim_yonetmeliYi_son_hali.pdf

*Moore-Mallinos, J. (2008a). Bende disleksi var [It's called dyslexia]. (E. Kılıç, Çev.; 1. baskı). TÜBİTAK Popüler Bilim Kitapları. (Orijinal kitabın yayın tarihi 2007)

"Moore-Mallinos, J. (2008b). Yapabilirim [It's ok to be me]. (E. Kılıç, Çev.; 1. baskı). TÜBİTAK Popüler Bilim Kitapları. (Orijinal kitabın yayın tarihi 2007)

"Moore-Mallinos, J. (2011). Down sendromlu bir arkadaşım var [My friend has Down syndrome]. (U. Hasdemir, Çev.; 10. baskı). TÜBİTAK Popüler Bilim Kitapları. (Orijinal kitabın yayın tarihi 2008)

*Moore-Mallinos, J. (2019). Duymamak böyle bir şey [I am deaf]. (Ö. Hanoğlu, Çev.; 1. baskı). TÜBİTAK Popüler Bilim Kitapları. (Orijinal kitabın yayın tarihi 2007)

"Noreau, D. (2018). Greg'in zaferleri [Les victoires de Grégoire: Une histoire sur... la dysphasie]. (Y. Varnal1, Çev.; 10. baskı). Yapı Kredi Yayınları. (Orijinal kitabın yayın tarihi 2010)

Odluyurt, S. (2018). Activities oriented to preparing children with disabilities for preschool inclusion. Elementary Education Online, 17(2), 1-18 https://doi.org/10.17051/ilkonline.2018.419358

*Oral, F. (2019). Farklı ama aynı. Yapı Kredi Yayınları.

*Oy, A. (2017). Dostluk engel tanımaz. Martı Yayıncılık.

Prater, M. A. (1999). Characterization of mental retardation in children's and adolescent literature. Education and Training in Mental Retardation and Developmental Disabilities, 34(4), 418-431.

"Pollack, P., \& Belsivo M. (2019). Bir türlü yerimde duramıyorum [I can't sit still]. (Ö. Hanbey, Çev.; 3. bask1). TÜBİTAK Popüler Bilim Kitapları. (Orjinal kitabın yayın tarihi 2009)

*Rodari, G. (2017). Mantova'nın cüceleri [I nani di Mantova]. (F. Özdem, Çev.; 1. baskı). Yapı Kredi Yayınları. (Orjinal kitabın yayın tarihi 2000)

Rubin, E., \& Watson, E. S. (1987). Disability bias in children's literature. The Lion and the Unicorn, 11(1), 60-67.

Sever, S. (2012). Çocuk ve edebiyat [Child and literature]. Tudem Yayıncılık.

Sucuoglu, N. B., Bakkaloglu, H., \& Demir, E. (2020). The effects of inclusive preschools on the development of children with disabilities: A longitudinal study. International Journal of Early Childhood Special Education, 12(1), 215-231. https://doi.org/10.9756/INT-JECSE/V12I1.201006

"Sunar, Ö. B. (2019). Yağmur adam ve en güzel dans [Rain-man and the most beautiful dance]. Sev Yayınc1lık

United Nations Educational, Scientific and Cultural Organization. (2013). Asia-Pacific end of decade note on education for all goal 1 on early childhood care and education. https://unesdoc.unesco.org/ark:/48223/pf0000217145

Ural, S. (2013). Okul öncesi çocuk kitaplarının tanımı. M. Gönen (Ed.), Çocuk edebiyatı [Child literature] içinde (ss. 33-55). Eğiten Kitap.

Weber, R. P. (1990). Basic content analysis (2nd ed.) Sage Publiciation.

*Yener, M. (2018). Gülümsemek iyidir [Smiling is good]. Tudem Yayın Grubu. 
Ek

\section{İncelemeye Alınmayan Kitaplar}

\section{Kitap İsmi \\ Kısa Kulaklı Tavşancık}

Benim Atım Farkl1

Disleksi Misleksi -

Tumburluplar

Topal Dev

Tekerlekli Sandalye

Ellerimdeki Kelimeler

Benim Otizmli Arkadaşım

Bücür Bora

Elimde Değil

Kuyruksuz
Yazar

Julia Liu

Esin Bacacı Taner

Meltem Erinçmen Kanoğlu

Oğuz Tansel

Bestami Yazgan

Benedicte Gourdon

Sue Adams

Ashley Spires

Holly L. Niner

Can Göknil
Yayınevi

Yapı Kredi Yayınları

Timaş Çocuk

Çikolata Yayınevi

Elips Kitap

Nar Çocuk

Desen Yayınevi

Sola Kidz

Meav Yayıncılık

TÜBİTAK Popüler Bilim Kitapları

Can Yayınları
Açıklama

Yetersizlik içermiyor.

Yetersizlik içermiyor.

Okul öncesi döneme uygun değil.

Okul öncesi döneme uygun değil.

Okul öncesi döneme uygun değil.

Resimli öykü kitabı özelliği taşımıyor

(Olay örgüsüne sahip değil).

Resimli öykü kitabı özelliği taşımıyor (Olay örgüsüne sahip değil).

Yetersizlik içermiyor.

Okul öncesi döneme uygun değil.

Yetersizlik içermiyor. 


\section{Ankara University Faculty of Educational Sciences Journal of Special Education}

2022, 23(1), 1-21
RESEARCH

Recieved Date: 01.07 .20

Accepted Date: 18.02 .20

OnlineFirst: 07.04.21

\title{
Examining Preschool Picture Storybooks about Individuals with Special Needs
}

\author{
Hüseyin Öztürk $(\mathbb{D} 1$
}

\author{
Kemal Afacan $(\mathbb{D})_{2}$
}

\author{
Seden Demirtaş-ilhan $(\mathbb{D} 3$
}

\begin{abstract}
Introduction: There is a need for awareness raising activities from the preschool period about individuals with special needs. Children's literature offers opportunities to enrich and deepen these studies. Examining the picture storybooks in the preschool period will be useful in increasing the awareness of children regarding individuals with special needs.

Method: In this study, preschool picture storybooks published since 2000 about individuals with special needs were analyzed using content analysis. A total of 20 books were included. In this study that was carried out using assessment scales included in the international liteature, the personal characteristics, character traits, character depictions, character development, and information about the point of view of the story, as well as the relationships between characters with and without special needs were examined.

Findings: Eight different special need conditions were identified in the 20 picture storybooks. Of the 20 books that were examined, physical disability in six studies, hearing impairment in four studies, intellectual disability in three studies, dyslexia in two studies, attention deficit and hyperactivity disorder in two studies, visual impairment in one study, autism in one study, and speech disorder in one study were the subject.

Discussion: While the variety of these conditions were similar to previous studies, the results regarding character development and relationships between characters differed. This study identified picture storybooks that could raise awareness towards individuals with special needs and provided recommendations for reading programs.
\end{abstract}

Keywords: Preschool, children, picture storybooks, disability, special needs.

To cite: Öztürk, H., Afacan, K., \& Demirtaş-İlhan, S. (2022). Examining preschool picture storybooks about individuals with special needs. Ankara University Faculty of Educational Sciences Journal of Special Education, 23(1), 1-21. https://doi.org/10.21565/ozelegitimdergisi.761001

${ }^{1}$ Corresponded Author: Assist. Prof., Artvin Çoruh University, E-mail: hsynztrk42@artvin.edu.tr, https://orcid.org/00000003-2876-4734

${ }^{2}$ Assist. Prof., Artvin Çoruh University, E-mail: kemalafacan@ artvin.edu.tr, https://orcid.org/0000-0002-2691-6397

${ }^{3}$ Res. Assist., Artvin Çoruh University, E-mail: sedendemirtas@artvin.edu.tr, https://orcid.org/0000-0003-2447-8482 


\section{Introduction}

Children's books are one of the resources that can be used to increase children's awareness about the topic of special needs. Direct contact with individuals with special needs positively affects both individuals with typical development and individuals with special needs (Sucuoğlu et al., 2020). However, not all children have the opportunity to communicate directly and continuously with individuals with disabilities. Books offer a number of opportunities for children to better understand other individuals' experiences. As Lukens (2002) indicate, it is virtually impossible for us to experience lives other than our own; however, the literature makes this possible for us. Moreover, Sever (2012) states that the literature prepares the environment for children to make inferences by establishing a link between their own lives and fictional lives. All these opportunities are also valid for the topic of special needs. Guiding students to read books related to special needs at every level of the educational process will contribute to minimizing unconscious attitudes towards individuals with special needs.

In classical works that have been adapted for children, the characters with special needs have been mostly specified with their negative and unrealistic features. Rubin and Watson (1987) identified 11 different types of patterns used to describe people with special needs in these classical works. These types varied widely from those depicted as a pitiful creature, to those who were objects of violence, those who suffered from themselves, those depicted as a burden to society, those who were isolated from society, and those with evil features. Tiny Tim in Charles Dicken's The Christmas Carol, Lennie in John Steinbeck's Of Mice and Men, and Clara in Johanna Spyri's Heidi are just a few examples given by these researchers. Many children have grown up by learning these features of characters with special needs in children's literature. However, this negative depiction of characters with special needs is not appropriate for children who will grow up in today's contemporary society (Dyches et al., 2010). In other words, it is very important in the change of social perspecive that individuals with special needs are depicted as dynamic characters and not as static stereotypical, asocial, and nonproductive characters.

Several books including characters with special needs have been published in recent years. These books need to draw a positive portrait towards the characters with special needs. Positive depictions mean: (a) high expectations are held for individuals with special needs, (b) positive contributions are taken into consideration, (c) strengths are emphasized, (d) individuals' choices are highlighted, (e) mutual relationships with other individuals are depicted, and (f) individuals with special needs are guaranteed to have equal citizenship rights as other individuals (Dyches \& Prater, 2005). In addition, characters with and without disabilities in the children's literature should be depicted as reliable, consistent, versatile, and constantly evolving individuals (Dyches \& Prater, 2000). Realistic depiction means that characters should represent all physical, behavioral, and language related aspects of a disability. It should also be noted that the traits of the characters are dynamic and can show a positive development over time (Dyches \& Prater, 2000).

Determining and examining preschool children's books related to individuals with special needs will be useful for researchers, psychotherapists, teachers, parents, and students who may want to read these books. There are some previous studies examining the same topic in the literature (Blaska, 2004; Dyches \& Prater, 2000; GürdalÜnal, 2014). For example, Prater (1999) analyzed the content of 68 children's books, including characters with intellectual disability, published between 1965 and 1996. Prater found that $61 \%$ of 77 characters with intellectual disability were the supporting characters in the books. Prater also found that $54 \%$ of the characters were static and did not show any development throughout the books. Only $13 \%$ of the books were told by characters with intellectual disability. Dyches et al. (2001) examined 12 books published in 1997-1998 and included characters with intellectual disability and autism spectrum disorder. The researchers found that $50 \%$ of the total 14 characters in the books were the main characters. Sixty-four percent $(64 \%)$ of the characters were depicted with realistic features and $71 \%$ with positive features. Fifty percent $(50 \%)$ of the characters were static throughout the books. In another study, Dyches and Prater (2005) presented a review of 34 books published between 1999 and 2003 and included characters with developmental disabilities. In this study, the researchers found that the characters with developmental disabilities were mostly able to make their own choices, were educated in inclusive educational environments, and were more accepted by the society in which they lived. In addition, characters with developmental disabilities had many features and their disabilities were just one of these features.

Gürdal-Ünal (2014) conducted one of the studies that examined the books including characters with special needs in Turkey. This study including 40 books published between 1969 and 2009 examined the changes in the living conditions of individuals with special needs and how these individuals were represented in children's literature. Quantitative data were not shared in this study; however, individuals with special needs and their relationships with family, school, friends, and their communities were revealed. The researcher found that historically individuals with special needs were stripped of their static and negative characteristics and were 
represented as dynamic and productive individuals. In another study, Kaymaz (2017) analyzed a total of 61 storybooks focusing on individuals with special needs. Kaymaz (2017) used the content analysis method to review the books' basic features, components, and formats. Results revealed that characters were mostly human, male, children, main character, dynamic, and positive. In addition, the most common disability status was emotional and behavioral disorder while intellectual disability, hearing impairment, and speech and language disorders were the least common disabilities in the books. Characters with special needs were often depicted as in need of help in problematic situations. However, they were in the position of assisting among very few books.

It is necessary to provide information about individuals with special needs at all levels of education. Odluyurt (2018) emphasized the importance of interactive reading activities in preparation for inclusion during pre-school period. Children should be asked open-ended questions about the characters and the context of the book and the answers received should be repeated and made more understandable (Ergül et al., 2014). For this reason, there is a need for research studies that functionally analyze books including characters with special needs published in the Turkish children's literature. We aim to address this need in the literature in this study.

\section{Methods}

In this study, special needs themed picture storybooks written for preschool children were examined. Twenty preschool picture storybooks published since 2000 were included in the review process. The study was carried out with content analysis method (Denzin \& Lincoln, 2000; Weber, 1990). In this research, the data obtained from the books were summarized, classified, and interpreted. Details on the process of determining the books and performing content analysis were explained below.

\section{Identifying Preschool Books}

Determining the books that would be reviewed is highly important (Dyches \& Prater, 2000). The selected books also constituted the sample group of the study. The criterion sampling method was used in the sample selection The criteria used for the sample of this study were: preschool picture storybooks and books that included characters with special needs. Printed and online sources were used during the sampling process. The sources used in this study were: online publishers, children's literature journals, accounts sharing book promotion and article reviews in social networks, online catalogs listing problem-oriented children's literature. We identified some keywords in the literature review. We used the following keywords: "disability", "disorder", "autism", "physical", "intellectual", "learning disability", "dyslexia", "hearing", "visual", "speech", "attention deficit", "hyperactivity". We identified 30 books after this initial search and applied four inclusion criteria to examine the preschool children's books.

The first criterion was that the books were published after 2000. This criterion was established in order to determine the current trends related to the topic. The second criterion was that the books were prepared for preschool children. We used both the age group labels on the books and the expert opinion to meet this criterion. In determining the age group, UNESCO's (United Nations Educational, Scientific and Cultural Organization) definition of early childhood was used. According to this definition, early childhood is between the ages of 0-8 (UNESCO, 2013). The third criterion was that the books included characters with special needs. Individuals with special needs refer to "individuals who differ significantly from their same age peers in terms of individual characteristics and educational competencies for various reasons" (Cavkaytar, 2019, p. 5). This definition includes all children with different characteristics who need special education. In this study, this definition includes intellectual disability, visual impairment, hearing impairment, orthopedic disability, autism, attention deficit and hyperactivity disorder, emotional or behavioral disorders, speech and language disorder, specific learning disability, and gifted and talented. The last criterion was that the books had to be children's picture story books. Ten of the books did not meet inclusion criteria. These 10 books were not included in the list of books examined within the scope of this study.

\section{Content Analysis and Coding}

The first step of the analysis was the determination of books recommended for preschool children. The Rating Scale for Quality Characterizations of Individuals with Disabilities in Children's Literature, which was developed by Dyches and Prater $(2000 ; 2005)$ and Dyches et al. $(2001)$, was used to analyze the books that were identified in this study. This scale was found to be appropriate in this research as it was created based on general literature standards as well as the description of individuals with special needs. The scale included four themes: (a) characterization of individuals with special needs, (b) the relationship of characters with other characters with and without special needs, (c) the change in individuals with and without special needs, and (d) special topics 
about special needs. At the same time, character depictions, social relationships, practices, and sibling relationships of individuals with special needs were taken into account along with literary and artistic elements (Dyches \& Prater, 2005; Dyches et al., 2001; Dyches et al., 2009).

\section{Coding Reliability}

The researchers in this study are experts who have studies in the Turkish Language Education, special education, and preschool education. All researchers were actively involved in the review and coding processes. Each researcher individually read 30 books and determined 20 books to be included in the final book list together. All of the books included in the final book list were read and analyzed by each researcher independently. The results of the content analysis were compared item-by-item for each book. An overall coding reliability was calculated. While calculating the coding reliabilty, "The number of agreements / (The number of agreements + The number of disagreements) X 100" formula was used (Kazdin, 2011, p. 104). The initial reliability of the 20 books analyzed in this study was calculated as $80 \%$ (range $=76-92$ ). The researchers discussed disagreements and resolved so that $100 \%$ agreement was reached.

\section{Results}

\section{Characterization of Individuals with Special Needs}

A total of 20 characters with special needs were represented in the 20 books reviewed. The number of dwarf characters in Mantova's dwarfs book was counted as one because the exact number of dwarf characters was unknown. Only one character was a non-human character (i.e., a goat). The remaining 19 characters consisted of people of different ages. The age group of characters with special needs ranged from a newborn boy to an adult woman with two children. In terms of gender, there were nine girls and twelve boys.

Topics focused on physical disability in six books (30\%), hearing impairment in four books $(20 \%)$, intellectual disability in four books $(20 \%)$, dyslexia in two books $(10 \%)$, attention deficit and hyperactivity disorder in two books (10\%), visual impairment in one book (5\%), dwarfs in one book (5\%) and speech disorder in one book $(5 \%)$. In the books that focused on individuals with intellectual disability, two books told the stories of characters with Down syndrome and one book a character with mild intellectual disability. A story of an individual with autism was told in one book.

While special needs situations were clearly stated in 17 books ( $85 \%)$, they were not named in three books $(15 \%)$. For example, in the "Hayal Satıcısı" book, it was stated that a mother with physical disability needed only a wheelchair without naming her specific disability. In five of the books (25\%), individuals with special needs did not need any help whereas in other 15 books (75\%) individuals with special needs needed help and their need level ranged from low to high. For example, in the "Kreşendo" book, Milo who had hearing impairment did not need intensive help from her grandmother to recognize sounds. On the other hand, in the book "Barış'ın Gezintisi", Barıș was a child with autism and he could not go out without the support of his sister. In addition, the materials that were used by individuals with special needs were examined. The materials mentioned in the books included wheelchairs, glasses, and a guide dog.

The results showed that realistic fiction was utilized in most of the books reviewed $(n=15)$. In five books, the characteristics and abilities of the characters with special needs made the books semi-realistic (25\%). In the books with realistic fiction, characters with special needs exhibited skills that were expected and appropriate for their special needs. For example, in the book "Greg'in Zaferleri", although Greg was not at the same level in speaking skills as his same age peers, he could draw very successfully and could develop himself in the field of taekwondo. In one of the unrealistic fiction books "Riki'nin Yeni Dünyası", Riki was a child with visual impairment who traveled the city by riding on the guide dog's back. Similarly, in the book "Yağmur Adam ve En Güzel Dans", a little girl with hearing impairment talked with an imaginary character named as Yağmur Adam and convinced Yağmur Adam to rain again.

Characters with special needs were portrayed as positive in 14 (70\%) of the books examined. In six books $(30 \%)$, characters with special needs were not portrayed as positive. In the book "Berke'nin Down Sendromu Hikayesi", Berke was described as an individual who made the whole family happy, made jokes, contributed to other family members, and had equal rights as other family members. Berke's special strengths, positive contributions to other characters, and constantly developing relationships were emphasized in the book. In the book "Yapabilirim" Adrian did not let his physical disability leave him behind his friends and he was selected for the school basketball team thanks to his efforts in many activities. In the book, it was highlighted that Adrian had 
overcome many difficulties with his determination and that people around him should not be afraid of him and his wheelchair.

"Farklı ama Aynı" is another book in which a character with special need was portrayed as positive. In the book, a non-human character with special need (i.e., a goat) was described. A goat with a physical disability both lived like other goats and contributed to the family by helping other goats. In the book "Down Sendromlu bir Arkadaşım Var", Tammy's (a child with Down syndrome) special ability in music was highlighted. Tammy encouraged her friends to participate in a music contest and had the opportunity to demonstrate her talents by playing the guitar.

"Içimdeki Aslan" was one of the books in which a character with special need was not portrayed as positive. Vaut had attention deficit and hyperactivity disorder and caused a mass in the home environment, exhibited excessive physical activities, and established negative relationships with family members. Similarly, in the book "Zoe Zor Ögreniyor", Zoe had negative relationships with her family members due to her intellectual disability. Zoe's negative characteristics were emphasized in the book.

Another content analysis was conducted on the development of the characters in the books. Character developments were operationalized as static or dynamic. Dynamic character development represented the developing and advancing characters throughout the stories whereas static characters did not. We found that 13 books portrayed dynamic characters (65\%) while seven books portrayed static characters (35\%). Ten books $(50 \%)$ were told from a third person perspective. Only five books $(25 \%)$ were told from the point of view of characters with special needs and the remaining five books (25\%) were told from the point of view of close friends and family members. The family structures depicted in the books were diverse. A family structure consisting of mothers, fathers, and siblings was commonly described across the books $(45 \%)$. In seven books, families were not mentioned (35\%), in one book ( $5 \%$ ) only a mother was mentioned, and large families consisting of family members such as aunt, uncle, and grandmother were described in the remaining books (15\%).

\section{The Relationships of Characters with Other Characters With and without Special Needs}

The relationships between characters with and without special needs in the books were grouped into six different themes: (a) primary relationships, (b) victim, perpetrator, and/or protector, (c) dependent and caregiver, (d) friendship, (e) pupil and instructor, and (f) fear of association. In a previous study, Dyches et al. (2001) examined a seventh relationship type (i.e., feelings of guilt) but we did not find examples of this relationship type in the books examined in this study.

The results showed that the two most common relationships among the characters with and without special needs were pupil-instructor $(n=9)$ and dependent-caregiver $(n=9)$. The pupil-instructor relationship took places in the school and home environments as well as near community. Although most of the pupil-instructor relationships took place in the school environment, in the book "Riki'nin Yeni Dünyası", Riki learned the Braille alphabet with the help of her grandmother. In pupil-instructor relationships, peers, parents, and siblings also assumed the role of instructor. Individuals with special needs were in the role of pupil in all books.

In the dependent-caregiver relationship, the caregiver was usually the person with which the individual with special needs was the closest. In the book "Berke'nin Down Sendromu", while the mother met all the needs of newborn Berke, his degree of dependency decreased as his age grew older. However, in the book "Hayal Satıclsı" a mother with physical disability continued to take care of her children.

The second most common type of relationship was friendship $(n=7)$. All of the friendship relationships were established between a character with special need and a typically developing character. Lastly, victim, perpetrator, and/or protector relationships $(n=4)$ were the third common relationship type in the books.

\section{Discussion}

Picture storybooks are one of the tools that can be used for educational and informative purposes related to special needs status in preschool years. In this study, we examined 20 preschool picture storybooks in terms of characters with special needs. By following the prior works of Dyches and Prater $(2000,2005)$ and Dyches et al. (2001), we examined the characterization of individuals with special needs and their relationships with individuals without special needs.

Six different disability types were identified across 20 preschool picture storybooks analyzed within the scope of this study. The specific categories included physical disabilities (6 books), intellectual disability (4 books), and hearing impairment (4 books). There were few preschool picture storybooks on specific learning 
disability and speech and language disorders that have high prevalence rates in special education. Also, no preschool books were identified on the subject of gifted and talented. This situation may lead to thinking that the characteristics of individuals with special needs are often associated with their visible characteristics such as using a wheelchair, a sign language, a cane, glasses, and Down syndrome. The reviewed books generally offered a variety of special needs situations. However, it should be noted that there needs to be a proportion between the characteristics of the characters and the actual prevalence rates of students with special needs during the presentation of these books to preschool children.

Characters with special needs were portrayed as positive in 14 books. In this study, a positive description was conceptualized as (a) high expectations were held for individuals with special needs, (b) the characters' positive contributions were taken into account, (c) strengths were presented, (d) individuals' choices were highlighted, (e) relationships were developed with other individuals, and (f) individuals with special needs were guaranteed to have equal citizenship rights as other individuals (Dyches et al., 2001). However, it should be highlighted that expectations, positive contributions to the society, strengths, character's choices and citizenship rights have been evaluated according to this age group as most of the characters with special needs were in their early childhood ages. Therefore, the characteristics of the age group limited the contribution to the society in a natural way in six studies. We took into consideration during the review of the books that children of this age could make limited contributions to the community in which they live.

We also found that 15 books were realistic and 5 books were semi-realistic. A detailed description of the existing potentials of characters with special needs was made in books with realistic fiction. At this point, our findings suggest a significant difference between the descriptions of characters with special needs in the last 10 years and the descriptions of characters with special needs in classical works. It is important to reflect the existing potentials of characters with special needs in children's books so that preschool children can read accurate information about these characters. Characters with special needs showed a dynamic aspect in 13 books $(65 \%)$. In only 7 books (35\%), the development of characters with special needs was found as static. Dynamic character development was one of the important findings in this study. Characters who demonstrated dynamic development were also portrayed with their realistic and positive descriptions. The results from this study revealed that more $(65 \%)$ characters with special needs were portrayed as dynamic, positive, and realistic compared to past studies on the same topic.

In this study, the relationships between the characters with special needs and other characters were examined in different dimensions. The most common type of relationship was the relationship between the characters with special needs and their instructors. Our results were not in an agreement with other studies in which researchers found the common relationship was between the characters with special needs and their peers (Dyches \& Prater, 2005) and between the characters with special needs and their siblings (Dyches et al., 2001). Presenting various relationships that characters with special needs establish with other characters is important to document their strengths in establishing, maintaining, and generalizing their social skills across people and environment. This could also mean that a realistic depiction could positively contribute to individuals with and without special needs. Preschool children who learn about such characters will have the opportunity to learn that individuals with special needs can have various communication skills and can use these skills to initiate and maintain relationships.

\section{Author's Contributions}

The authors equally contributed to all phases of this study. 